\title{
Additions to Philippine slender skinks of the Brachymeles bonitae complex (Reptilia: Squamata: Scincidae) IV: Resurrection and redescription of Brachymeles burksi
}

\author{
Cameron D. Siler ${ }^{1,2, *}$, Elyse S. Freitas ${ }^{1,2}$, Jennifer A. Sheridan ${ }^{3}$, Stephanie N. Maguire ${ }^{1}$, Drew R. Davis ${ }^{4}$, \\ Jessa L. Watters' ${ }^{2}$ Kai Wang ${ }^{1,2}$, Arvin C. Diesmos ${ }^{5}$, and Rafe M. Brown ${ }^{6}$
}

\begin{abstract}
The diversity of Philippine amphibians and reptiles has increased over the last few decades, in part due to re-evaluation of species formerly believed to be widespread. Many of these investigations of widespread species have uncovered multiple closely related cryptic lineages comprising species complexes, each restricted to individual Pleistocene Aggregate Island Complexes (PAICs). One group in particular for which widespread cryptic diversity has been common is the clade of Philippine skinks of the genus Brachymeles. Recent phylogenetic studies of the formerly recognized widespread species Brachymeles bonitae have indicated that this species is actually a complex distributed across several major PAICs and smaller island groups in the central and northern Philippines, with numerous species that exhibit an array of digit loss and limb reduction patterns. Despite the recent revisions to the $B$. bonitae species complex, studies suggest that unique cryptic lineages still exist within this group. In this paper, we resurrect the species Brachymeles burksi Taylor 1917, for a lineage of non-pentadactyl, semi-fossorial skink from Mindoro and Marinduque islands. First described in 1917, B. burksi was synonymized with $B$. bonitae in 1956, and has rarely been reconsidered since. Evaluation of genetic and morphological data (qualitative traits, meristic counts, and mensural measurements), and comparison of recently-obtained specimens to Taylor's original description support this species' recognition, as does its insular distribution on isolated islands in the central portions of the archipelago. Morphologically, B. burksi is differentiated from other members of the genus based on a suite of unique phenotypic characteristics, including a small body size, digitless limbs, a high number of presacral vertebrae, the absence of auricular openings, and discrete (non-overlapping) meristic scale counts. The recognition of this central Philippine species further increases the diversity of non-pentadactyl members of the $B$. bonitae complex, and reinforces the biogeographic uniqueness of the Mindoro faunal region.
\end{abstract}

Keywords: biodiversity, endemism, faunal region, fossoriality, limb reduction

${ }^{1}$ Department of Biology, University of Oklahoma, Norman, Oklahoma, USA

${ }^{2}$ Sam Noble Oklahoma Museum of Natural History, University of Oklahoma, Norman, Oklahoma, USA

${ }^{2}$ Carnegie Museum of Natural History, Pittsburgh, Pennsylvania, USA ${ }^{4}$ School of Earth, Environmental, and Marine Sciences, University of Texas Rio Grande Valley, South Padre Island, Texas, USA

${ }^{5}$ Herpetology Section, Zoology Division, Philippine National Museum, Rizal Park, Burgos St., Manila, Philippines

${ }^{6}$ Biodiversity Institute and Department of Ecology and Evolutionary Biology, University of Kansas, Lawrence, Kansas, USA

*Corresponding email: camsiler@ou.edu

Date Submitted: 14 May 2019

Date Accepted: 11 September 2020

\section{Introduction}

The Philippine Archipelago, composed of more than 7,100 islands in the western Pacific Ocean, is recognized globally as one of only two countries designated as both a megadiverse nation and a biodiversity hotspot (Mittermeier et al. 1999; Brown et al. 2013; Diesmos et al. 2015). As such, identifying and understanding species-level diversity across the archipelago is critical to developing effective conservation strategies. Despite focused biodiversity assessments over the last century, species continue to be described for a number of vertebrate groups, particularly among amphibians and reptiles, which have experienced substantial increases in recognized diversity in the last decade alone (e.g. Siler et al. 2009, 2010a,b, 2014a; Siler \& Brown 2010; Davis et al. 2014, 2016). A component of this new diversity has resulted from close evaluation of poorly understood species complexes that were formerly considered to 
be single species spanning multiple Pleistocene Aggregate Island Complexes (PAICs; Brown \& Diesmos 2002, 2009). In many cases, analyses of both molecular and morphological data from members of these species complexes have led to the identification of multiple lineages, often with individual species restricted to a single PAIC (e.g. Welton et al. 2009, 2010a,b; Siler et al. 2010a,b, 2011a; Siler \& Brown 2010). Cumulatively, these systematic studies have further increased the remarkable level of endemism among amphibians and reptiles in the Philippines and reinforced the significance of the PAIC paradigm for understanding terrestrial vertebrate species distributions in the archipelago (Brown \& Diesmos 2009).

One group of reptiles in particular that has seen a tremendous increase in recognized diversity in the country is the genus Brachymeles (family Scincidae). Of the 41 species recognized currently (Davis et al. 2014, 2016; Geheber et al. 2016; Siler et al. 2016), all but two are endemic to the Philippines (B. apus Hikida occurs in Borneo, B. miriamae Heyer occurs in Thailand; Heyer 1972; Hikida 1982; Siler et al. 2009, 2010a,b, 2011a,b,c,d, 2012a, 2016; Siler 2010; Siler \& Brown 2010, 2011; Davis et al. 2014, 2016; Geheber et al. 2016). All members of the genus are secretive, slender-bodied, semi-fossorial lizards often found in leaf litter and decomposing organic matter (i.e., decaying coconut husks, rotting tree logs; Davis et al. 2014, 2016; Geheber et al. 2016; Siler et al. 2016). Interestingly, the clade is one of only five skink genera known to have pentadactyl, non-pentadactyl, and externally limbless species (Siler \& Brown 2011; Wagner et al. 2018). Furthermore, digit numbers vary among non-pentadactyl species (Siler et al. 2011a), and some instances of intraspecific digit variation have been documented (Siler et al. 2009, 2011b).

Despite the long-recognized variation in limb and digit states, a suite of studies have highlighted general similarity in external morphological appearances, with the similar "burrowing" skink ecomorphologies making it difficult to identify species boundaries (Siler et al. 2009, 2010a,b, 2011a,b,c,d, 2012a, 2016; Siler 2010; Siler \& Brown 2010, 2011; Davis et al. 2014; Geheber et al. 2016). However, with improved population-level sampling across much of the Philippines and robust estimates of phylogenetic relationships, the number of species recognized in the genus has expanded from 17 to 41 since 2009 (e.g. Siler \& Brown 2010; Siler et al. 2011d; Davis et al. 2014). Furthermore, several species complexes have now been identified, one of the most diverse of which is the B. bonitae group (Davis et al. 2014, 2016; Geheber et al. 2016; Siler et al. 2016).

The genus Brachymeles was described for the small, limbreduced, non-pentadactyl species $B$. bonitae Duméril \& Bibron, which was found on Luzon Island near the capital city of
Manila (Duméril \& Bibron 1839). Subsequently, Taylor (1917) described another small, non-pentadactyl species, B. burksi Taylor from Mindoro Island, based on a single examined specimen (CM 1975 [Field No. EHT 700]). By the time Brown (1956) published a systematic review of the genus, significant character variation was recognized among sampled populations of B. bonitae and between B. bonitae and B. burksi. However, likely due to low sample sizes across island populations and general body plan similarity, Brown (1956) synonymized $B$. burksi with $B$. bonitae, and the Mindoro Island population would remain part of this widespread species complex for almost 60 years (Brown 1956; Davis et al. 2014).

Currently, there are seven species recognized in the $B$. bonitae complex, all limbed but non-pentadactyl, with the number of digits on each limb ranging from 0-3 fingers and toes (Davis et al. 2014, 2016; Geheber et al. 2016; Siler et al. 2016). However, it is suspected that additional unrecognized diversity remains, and genetic and morphological data indicate that the populations of $B$. bonitae on Mindoro and Marinduque islands are distinct from congeners but only weakly distinguished from each other (Wagner et al. 2018). These datasets support the Mindoro + Marinduque island populations as a distinct evolutionary lineage worthy of formal recognition, rather than as isolated populations of $B$. bonitae (Wagner et al. 2018). Based on a suite of unique phenotypic characteristics, and supported by analyses of phylogenetic relationships, we resurrect the name $B$. burksi Taylor 1917 for this lineage of non-pentadactyl, semifossorial skink. Additionally, we discuss this species' geographic distribution and natural history.

\section{Materials and Methods}

\section{Field work, sample collection, and specimen preservation}

Fieldwork was conducted on Camiguin Norte, Catanduanes, Lubang, Luzon, Marinduque, Masbate, Mindoro, Polillo, Sibuyan, and Tablas Islands, all in the Philippines, between 1991 and 2012 (Fig. 1). Specimens were collected during the day, euthanized with MS-222, dissected for tissue samples (liver preserved in 95\% ethanol), fixed in 10\% buffered formalin and eventually $(<2 \mathrm{mo})$ transferred to $70 \%$ ethanol for long-term storage. Specimens are deposited in U.S. and Philippine museum collections (see Appendix I). Museum abbreviations for specimens examined follow those from Sabaj (2019).

\section{Molecular data and phylogenetic analyses}

We collected and aligned novel sequence data from two vouchered individuals of $B$. cf. bonitae from Marinduque Island (KU 320417, 320418) with the published dataset of Davis et al. 


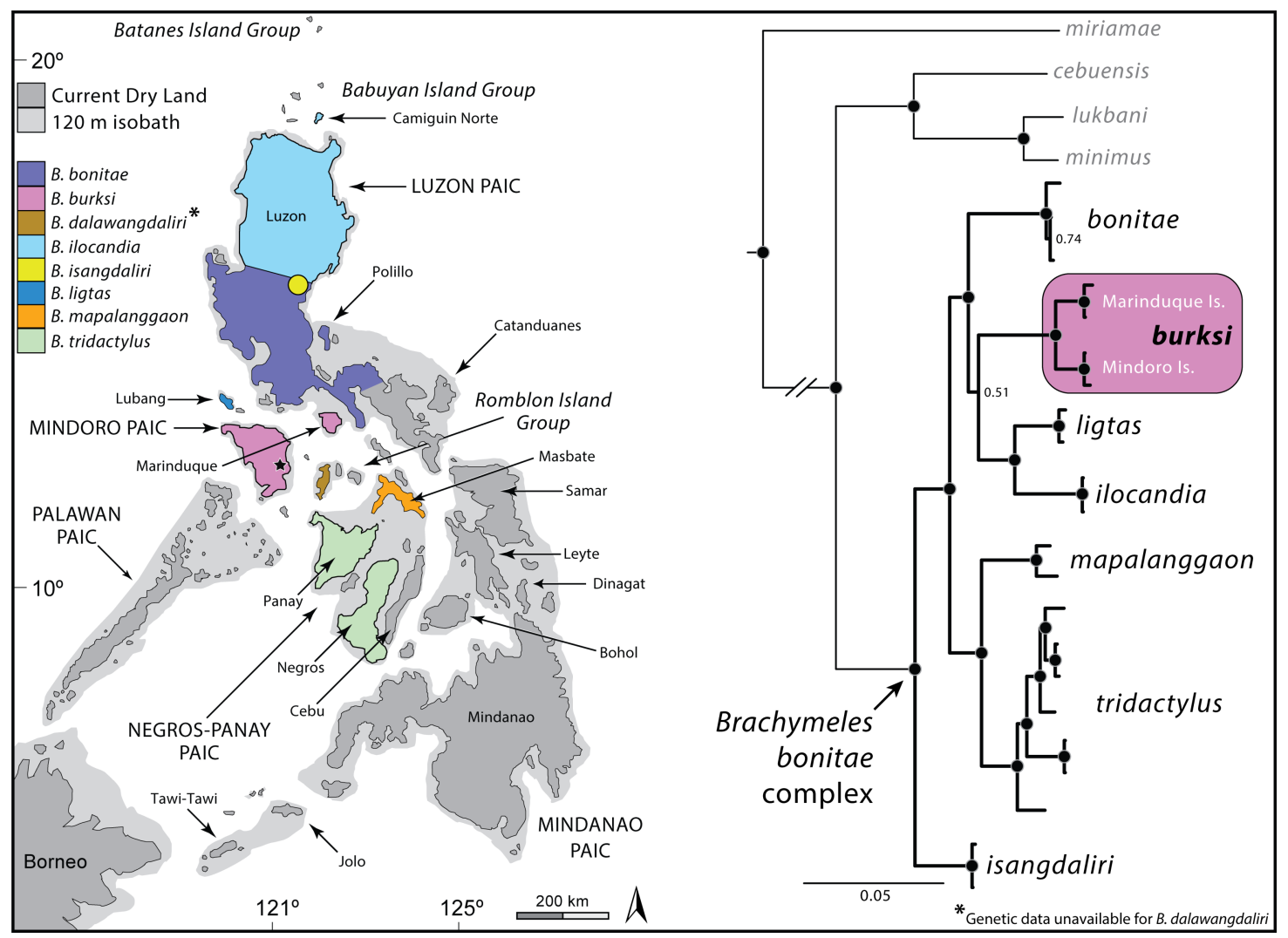

Figure 1. (Left) Map of the Philippines, with names for focal islands, major faunal regions (PAICs), and isolated island groups provided for reference. Colored islands correspond to the current distribution of species in the Brachymeles bonitae complex, with light purple representing the hypothesized distribution of $B$. burksi and the black star on Mindoro Island designating its type locality (Taylor, 1917). The light gray outlines represent $120 \mathrm{~m}$ bathymetric contours, showing the hypothesized maximum extent of land during the mid- to late Pleistocene. (Right) Maximum clade credibility topology of focal lineages of Brachymeles, with members of the $B$. bonitae complex emphasized with black branches and B. burksi highlighted in light purple. Outgroup samples used in the study (Lygosoma siamensis) have been trimmed from the tree. Node circles indicate high support (Bayesian posterior probability $\geq 0.95)$.

(2014) available on GenBank, which included multiple sequences from the six previously described species in the $B$. bonitae complex (B. bonitae, B. ilocandia Siler et al., $B$. isangdaliri Davis et al., $B$. ligtas Geheber et al., $B$. mapalanggaon Davis et al., and B. tridactylus Brown), as well as two specimens of $B$. cf. bonitae from Mindoro Island. No genetic samples were available for inclusion of $B$. dalawangdaliri Davis et al. at the inception of our study, so that recently described species (Davis et al. 2017) was not included here (but see Meneses et al. 2020; this volume). We also included sequences of Lygosoma siamensis Siler et al. (formerly L. quadrupes [Siler et al. 2018]) from GenBank as outgroup lineages following the methods and results of several previous phylogenetic studies of Brachymeles (Davis et al. 2014; Siler \& Brown 2011; Siler et al. 2011a; Wagner et al. 2018). A total of 28 samples were used in the phylogenetic analyses.

For the two vouchered samples from Marinduque Island, we extracted total genomic DNA from tissues using a modified guanidine thiocyanate extraction method (Esselstyn et al. 2008). Using the primers and protocols provided in Siler and Brown (2011) and Siler et al. (2011a), we sequenced the mitochondrial NADH dehydrogenase subunit 1 (ND1) gene and two proteincoding nuclear loci: brain-derived neurotrophic factor (BDNF) and prostaglandin E2 receptor type 4 (PTGER4). Novel sequences were deposited in GenBank (Accession Nos.: MT813048, MT813049 [ND1]; MT813050, MT813051 [BDNF]; MT813052, MT813053 [PTGER4]).

Initial alignments were produced in MUSCLE (Edgar 2004) and checked by eye; the alignment required minimal subsequent manual adjustments. We assessed phylogenetic congruence between the mitochondrial and nuclear data by estimating individual gene trees using Bayesian analyses. As observed previously (Davis et al. 2014), no moderate to highly supported incongruence between datasets was found, and therefore, we felt justified in using the combined, concatenated data for subsequent analyses. 
Table 1. Table showing the substitution models used for each partition in model-based phylogenetic analysis.

\begin{tabular}{ccc}
\hline Gene & Partition & Substitution Model \\
\hline \multirow{3}{*}{ BDNF } & $1^{\text {st }}$ codon position & GTR \\
& $2^{\text {nd }}$ codon position & HKY \\
& $3^{\text {rd }}$ codon position & GTR $+\Gamma$ \\
& $1^{\text {st }}$ codon position & HKY $+\Gamma$ \\
PTGER4 & $2^{\text {nd }}$ codon position & HKY \\
& $3^{\text {rd }}$ codon position & GTR $+\Gamma$ \\
& $1^{\text {st }}$ codon position & GTR $+\Gamma$ \\
& $2^{\text {nd }}$ codon position & GTR $+\Gamma$ \\
& $3^{\text {rd }}$ codon position & GTR $+\Gamma$ \\
\hline
\end{tabular}

Partitioned Bayesian analyses were conducted in MrBayes v3.2.6 (Ronquist \& Huelsenbeck 2003). The alignment was partitioned into nine regions consisting of the codon positions of ND1 and the two nuclear loci, BDNF and PTGER4, following the methods of Siler et al. (2011a) and Davis et al. (2014). The Akaike Information Criterion (AIC), as implemented in jModelTest v2.1.4 (Guindon \& Gascuel 2003; Darriba et al. 2012), was used to select the best model of nucleotide substitution for each partition (Table 1). A rate multiplier model was used to allow substitution rates to vary among subsets, and default priors were used for all model parameters. We ran four independent Markov chain Monte Carlo (MCMC) analyses, each with four Metropolis Coupled chains, an incremental heating temperature of 0.02 , and an exponential distribution with a rate parameter of 75 as the prior on branch lengths (Marshall 2010). All analyses were run for five million generations, with parameters and topologies sampled every 5,000 generations. We assessed stationarity and convergence of parameters with Tracer v1.7.1 (Rambaut \& Drummond 2007). We conservatively discarded the first $10 \%$ of samples as burnin. We considered topologies with posterior probabilities 0.95 to be well supported (Leaché \& Reeder 2002; Wilcox et al. 2002). Additionally, we calculated percentage uncorrected pairwise distances for all species in the $B$. bonitae species complex (Table 2) in R v3.5.3 (R Core Team 2019) using the command dist.dna in the package ape v5.2 (Paradis \& Schliep 2018).

\section{Morphological data and multivariate analyses}

Meristic (scale counts) and mensural (measurements) characters were taken from fluid-preserved specimens following Siler et al. $(2009,2010 a, b)$. Measurements were taken to the nearest $0.1 \mathrm{~mm}$ with digital calipers and the sex of each specimen was determined by gonadal inspection. Characters evaluated included: snout-vent length (SVL); axilla-groin distance (AGD); tail length (TL); tail width (TW); total length (TotL); fore-limb length (FLL); hind limb length (HLL); head width (HW); head length (HL); snout length (SNL); eye-nares distance (END); midbody width (MBW); midbody height (MBH); midbody scale-row counts (MBSR); axilla-groin scalerow counts (AGSR); paravertebral scale-row counts (PVSR); supralabial scale counts (SL); infralabial scale counts (IFL); superciliary scale count (SC); supraocular scale count (SO); prefrontal contact; frontoparietal contact; $1^{\text {st }}$ chin shield pair contact; $3^{\text {rd }}$ chin shield pair presence, contact; mental $/ 1^{\text {st }}$ infralabial scale fusion; enlarged nuchals; and the presence of longitudinal rows of dark spots along the body.

Following the observation that several of the digitless members of the $B$. bonitae complex, specifically $B$. ilocandia and $B$. cf. bonitae from Mindoro and Catanduanes islands, displayed broadly overlapping state ranges for characters often used to diagnose taxa in the genus, we employed Principle Component Analysis (PCA) to determine if the four digitless species (i.e. B. cf. bonitae (Mindoro + Marinduque), B. bonitae, $B$. ilocandia, and B. mapalanggaon) occupy distinct regions of morphospace. Given the conservative nature of most meristic

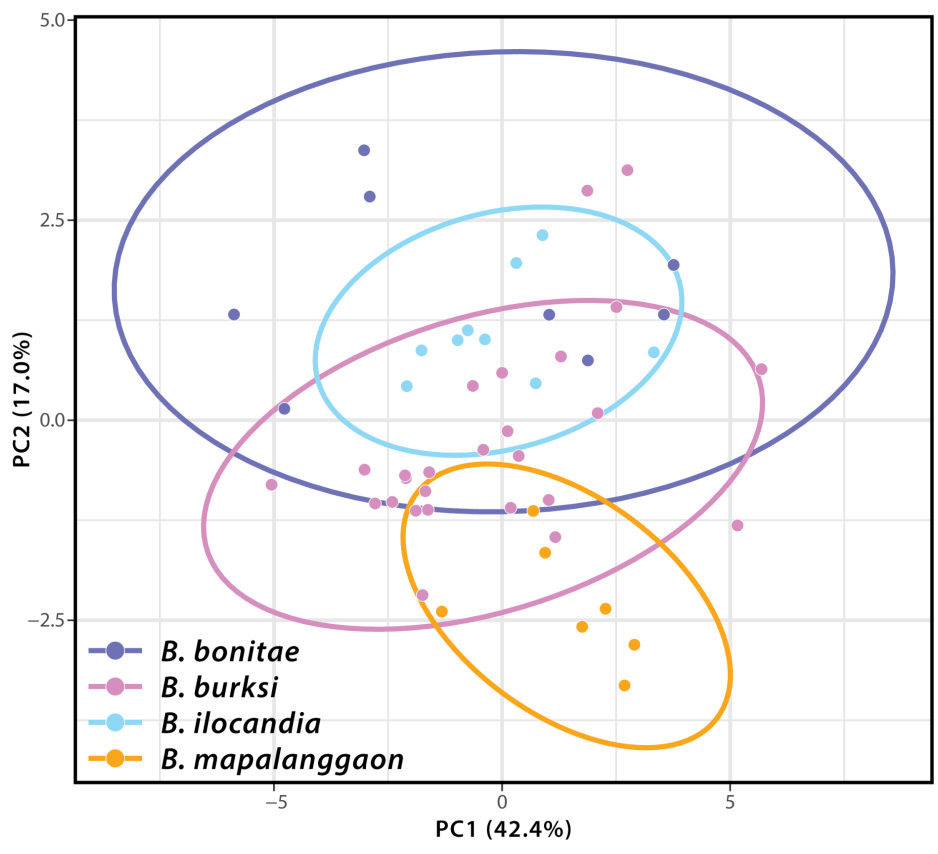

Figure 2. Principle Component Analysis (PCA) plot of the first two major principle components (PCs) with 95\% confidence ellipses based on 15 mensural characters (SVL, AGD, MBW, MBD, TW, TD, HL, HW, HD, ED, END, SNL, IND, ForeL, and HindL) for the four digitless members of the Brachymeles bonitae complex. The first two PCs account for $59.4 \%$ of the total variance, which loads most heavily on SVL and AGD for PC1 and HD and HindL for PC2 (Appendix II). Colors correspond to species-specific colors shown in Figure 1. See methods for description of abbreviations. 
Table 2. Table showing the minimum and maximum uncorrected pairwise genetic distances between each species in the Brachymeles bonitae species complex. No genetic samples or sequence data were available for B. dalawangdaliri (but see Meneses et al. 2020, this volume). Distances above the diagonal line and shaded in gray represent the mitochondrial genetic distances (ND1), with the numbers in bold representing the intraspecific mitochondrial distances. Distances below the diagonal line and shaded in white represent the nuclear genetic distances, with the top number representing BDNF and the bottom number representing PTGER4. The number in parentheses next to the species name indicates the total number of sequences for each species used in the calculations.

\begin{tabular}{|c|c|c|c|c|c|c|c|}
\hline & bonitae (3) & burksi (4) & ilocandia (2) & isangdaliri (2) & ligtas (2) & mapalaggoan (2) & tridactylus (7) \\
\hline bonitae & $0.2-1.5$ & $9.9-10.6$ & $9.4-9.7$ & $9.4-10.0$ & $8.8-9.4$ & $9.0-11.1$ & $8.6-9.6$ \\
\hline burksi & $\begin{array}{c}0.1-0.7 \\
0.2\end{array}$ & $0.6-4.3$ & $10.3-10.9$ & $10.2-11.3$ & $9.3-9.9$ & $10.0-11.8$ & $9.4-11.4$ \\
\hline ilocandia & $\begin{array}{l}0.1 \\
0.4\end{array}$ & $\begin{array}{c}0.0-0.6 \\
0.2\end{array}$ & 0.0 & 10.5 & $6.9-7.0$ & $10.5-11.2$ & $10.5-11.0$ \\
\hline isangdaliri & $\begin{array}{l}0.1 \\
0.4\end{array}$ & $\begin{array}{c}0.3-0.8 \\
0.2\end{array}$ & $\begin{array}{l}0.3 \\
0.4\end{array}$ & 0.0 & 10.0 & $10.4-11.2$ & $9.4-10.3$ \\
\hline ligtas & $\begin{array}{l}0.1 \\
0.2\end{array}$ & $\begin{array}{c}0.0-0.6 \\
0.4\end{array}$ & $\begin{array}{l}0.0 \\
0.6\end{array}$ & $\begin{array}{l}0.3 \\
0.2\end{array}$ & 0.7 & $10.3-11.1$ & $9.8-10.2$ \\
\hline mapalaggoan & $\begin{array}{l}0.3 \\
0.6\end{array}$ & $\begin{array}{c}0.1-0.7 \\
0.4\end{array}$ & $\begin{array}{l}0.1 \\
0.6\end{array}$ & $\begin{array}{l}0.1 \\
0.2\end{array}$ & $\begin{array}{l}0.1 \\
0.4\end{array}$ & 2.6 & $7.8-8.8$ \\
\hline tridactylus & $\begin{array}{l}0.3-0.6 \\
0.2-0.6\end{array}$ & $\begin{array}{c}0.1-1.0 \\
0.4\end{array}$ & $\begin{array}{c}0.1-0.4 \\
0.6\end{array}$ & $\begin{array}{c}0.1-0.4 \\
0.2\end{array}$ & $\begin{array}{c}0.1-0.40 \\
0.0-0.4\end{array}$ & $\begin{array}{l}0.0-0.3 \\
0.0-0.4\end{array}$ & $0.0-5.0$ \\
\hline
\end{tabular}

characters observed for the four morphologically similar, digitless taxa, only mensural characters were used for subsequent morphological analyses. We excluded TotL and TL due to incomplete sampling resulting from missing or partially regenerated tails present on examined specimens. All remaining mensural characters were square root transformed and scaled to their standard deviation to ensure data normality, and PCA analyses were performed using the prcomp command in $\mathrm{R}$ v.3.2.1 (R Core Team 2019). The first two major principle components (PCs) were plotted using ggplot2 in R with $95 \%$ confidence ellipses (Fig. 2).

\section{Species concept}

We use the General Lineage species concept (de Queiroz 1998, 1999) to recognize the evolutionary lineage distributed on Mindoro and Marinduque islands as a distinct species. Following this concept, we consider a species to be an independently evolving lineage with a unique evolutionary history that is distinct from other such species (de Queiroz 1998). We use morphological, phylogenetic, and geographic evidence to facilitate the recognition of the Mindoro and Marinduque island populations as a separate species, evolving independently from its closest relatives in the $B$. bonitae complex.

\section{Results}

\section{Phylogenetic relationships and genetic divergence}

All analyses recovered populations of $B$. cf. bonitae from Mindoro and Marinduque islands as a monophyletic group nested within the $B$. bonitae complex (Fig. 1). Although this divergent lineage is supported to be closely related to true $B$. bonitae, $B$. ilocandia, and $B$. ligtas, its sister relationship to the well supported clade of $B$. ilocandia $+B$. ligtas received only moderate support (Fig. 1). Given the absence of available genetic material for $B$. dalawangdaliri at the time of finalizing this study, the relationship of $B$. burksi to the Romblon Island Group endemic was not available for evaluation. However, more recent collection of a vouchered genetic sample of $B$. dalawangdaliri allowed for Meneses et al. (2020; this volume) to confirm its placement within the $B$. bonitae complex. The results of these new analyses are consistent with relationships inferred in this study, but also show support for $B$. dalawangdaliri as a divergent lineage nested within the $B$. bonitae complex and sister to a clade composed of $B$. bonitae, $B$. burksi, B. ilocandia, B. ligtas, and two undescribed species (Meneses et al. 2020:fig. 6; this volume).

With two exceptions, genetic divergences among lineages within the $B$. bonitae complex are much greater than intraspecific genetic diversity (Table 2). Both $B$. cf. bonitae (Mindoro + Marinduque) and B. tridactylus show moderate 
Table 3. Summary of meristic and mensural characters among species of the Brachymeles bonitae complex. Sample size, body length and total length among males and females, and general geographical distribution (PAIC = Pleistocene Aggregate Island Complexes, sensu Brown \& Diesmos [2002]) are included for reference (SVL, TotL, FLL, and HLL given as range over mean \pm standard deviation; all body proportions given as percentage over mean \pm standard deviation).

\begin{tabular}{|c|c|c|c|c|c|c|c|c|}
\hline & $\begin{array}{c}\text { burksi } \\
(19 \mathrm{~m}, 19 \mathrm{f})\end{array}$ & $\begin{array}{c}\text { bonitae } \\
\text { (3 m, } 1 \mathrm{f})\end{array}$ & $\begin{array}{l}\text { dalawangdaliri } \\
(2 \mathrm{~m}, 5 \mathrm{f})\end{array}$ & $\begin{array}{l}\text { ilocandia } \\
\text { (9 f) }\end{array}$ & $\begin{array}{l}\text { isangdaliri } \\
\text { (1 f f) }\end{array}$ & $\begin{array}{c}\text { ligtas } \\
(3 \mathrm{~m}, 2 \mathrm{f})\end{array}$ & $\begin{array}{l}\text { mapalanggaon } \\
\quad(3 \mathrm{~m}, 6 \mathrm{f})\end{array}$ & $\begin{array}{l}\text { tridactylus } \\
(12 \mathrm{~m}, 9 \mathrm{f})\end{array}$ \\
\hline $\begin{array}{l}\text { Range } \\
\text { (islands) }\end{array}$ & $\begin{array}{l}\text { Mindoro \& } \\
\text { Marinduque }\end{array}$ & Luzon \& Polillo & Tablas & $\begin{array}{c}\text { Luzon \& } \\
\text { Camiguin Norte }\end{array}$ & Luzon & Lubang & Masbate & $\begin{array}{c}\text { West Visayan } \\
\text { PAIC }\end{array}$ \\
\hline SVL (f) & $\begin{array}{c}68.8-77.5 \\
(74.4 \pm 2.5)\end{array}$ & 69.4 & $\begin{array}{c}69.8-80.9 \\
(73.6 \pm 4.4)\end{array}$ & $\begin{array}{c}65.7-77.6 \\
(73.7 \pm 3.7)\end{array}$ & 59.5 & $\begin{array}{c}60.7-69.2 \\
(65.0 \pm 6.0)\end{array}$ & $\begin{array}{c}61.7-75.8 \\
(67.2 \pm 5.4)\end{array}$ & $\begin{array}{c}59.9-82.3 \\
(71.4 \pm 6.9)\end{array}$ \\
\hline $\operatorname{SVL}(\mathrm{m})$ & $\begin{array}{c}58.4-77.0 \\
(68.9 \pm 5.0)\end{array}$ & $\begin{array}{c}69.7-78.4 \\
(72.8 \pm 4.8)\end{array}$ & $\begin{array}{c}66.0-74.9 \\
(70.4 \pm 6.3)\end{array}$ & N/A & $\mathrm{N} / \mathrm{A}$ & $\begin{array}{c}69.4-79.6 \\
(74.5 \pm 5.1)\end{array}$ & $\begin{array}{c}65.1-72.7 \\
(68.4 \pm 3.9)\end{array}$ & $\begin{array}{c}60.7-77.6 \\
(69.0 \pm 6.0)\end{array}$ \\
\hline $\operatorname{TotL}(\mathrm{f})$ & $\begin{array}{l}125.4-145.3 \\
(137.1 \pm 5.9)\end{array}$ & $\mathrm{N} / \mathrm{A}$ & N/A & $\begin{array}{c}122.3-146.0 \\
(134.1 \pm 8.0)\end{array}$ & 106.1 & 119.4 & 120.2 & $133.6^{\mathrm{a}}$ \\
\hline TotL (m) & $\begin{array}{c}107.8-138.0 \\
(122.4 \pm 11.1)\end{array}$ & 122.0 & N/A & N/A & N/A & 160.6 & $\begin{array}{l}112.6-118.6 \\
(115.6 \pm 4.3)\end{array}$ & $\begin{array}{c}120.9-154.1 \\
(136.0 \pm 9.8)\end{array}$ \\
\hline TL/SVL & $\begin{array}{c}61-93 \\
(81 \pm 10)\end{array}$ & 73 & N/A & $\begin{array}{l}81-90 \\
(85 \pm 3)\end{array}$ & 78 & $\begin{array}{l}97-102 \\
(99 \pm 4)\end{array}$ & $\begin{array}{c}67-84 \\
(78 \pm 9)\end{array}$ & $\begin{array}{c}85-112 \\
(95 \pm 10)\end{array}$ \\
\hline FLL & $\begin{array}{c}0.9-1.5 \\
(1.2 \pm 0.1)\end{array}$ & $\begin{array}{c}1.0-1.7 \\
(1.3 \pm 0.3)\end{array}$ & $\begin{array}{c}1.4-2.2 \\
(1.9 \pm 0.3)\end{array}$ & $\begin{array}{c}1.1-1.4 \\
(1.3 \pm 0.1)\end{array}$ & 1.3 & $\begin{array}{c}1.2-1.4 \\
(1.3 \pm 0.1)\end{array}$ & $\begin{array}{c}0.8-1.0 \\
(0.9 \pm 0.1)\end{array}$ & $\begin{array}{c}1.5-2.5 \\
(2.0 \pm 0.3)\end{array}$ \\
\hline FLL/SVL & $\begin{array}{c}1-2 \\
(2 \pm 0)\end{array}$ & $\begin{array}{c}1-2 \\
(2 \pm 0)\end{array}$ & $\begin{array}{c}2-3 \\
(3 \pm 0)\end{array}$ & $\begin{array}{c}1-2 \\
(2 \pm 0)\end{array}$ & 2 & $\begin{array}{c}2-2 \\
(2 \pm 0)\end{array}$ & $\begin{array}{c}1-2 \\
(1 \pm 0)\end{array}$ & $\begin{array}{c}2-4 \\
(3 \pm 0)\end{array}$ \\
\hline HLL & $\begin{array}{c}1.2-1.9 \\
(1.6 \pm 0.2)\end{array}$ & $\begin{array}{c}1.5-2.3 \\
(1.9 \pm 0.3)\end{array}$ & $\begin{array}{c}1.9-2.2 \\
(2.1 \pm 0.1)\end{array}$ & $\begin{array}{c}1.6-1.9 \\
(1.8 \pm 0.1)\end{array}$ & 2.2 & $\begin{array}{c}1.6-2.0 \\
(1.8 \pm 0.1)\end{array}$ & $\begin{array}{c}1.2-1.6 \\
(1.4 \pm 0.1)\end{array}$ & $\begin{array}{c}2.6-3.6 \\
(3.1 \pm 0.3)\end{array}$ \\
\hline HLL/SVL & $\begin{array}{c}2-3 \\
(2 \pm 0)\end{array}$ & $\begin{array}{c}2-3 \\
(3 \pm 0)\end{array}$ & $\begin{array}{c}2-3 \\
(3 \pm 0)\end{array}$ & $\begin{array}{c}2-3 \\
(2 \pm 0)\end{array}$ & 4 & $\begin{array}{c}2-3 \\
(3 \pm 0)\end{array}$ & $\begin{array}{c}2-2 \\
(2 \pm 0)\end{array}$ & $\begin{array}{c}3-6 \\
(5 \pm 1)\end{array}$ \\
\hline
\end{tabular}

\footnotetext{
${ }^{a}$ Only a single adult female was available with an original tail for measurement.
} 
Table 4. Summary of meristic and qualitative diagnostic characters (present, absent) among species of the Brachymeles bonitae complex. The pairs of enlarged scales posterior to the postmental scale are abbreviated as chin shield pairs with reference to the $1^{\text {st }}, 2^{\text {nd }}$, and $3^{\text {rd }}$ pairs (when present). In cases of scale count variation within species, numbers of individuals showing specific counts are given in parentheses.

\begin{tabular}{|c|c|c|c|c|c|c|c|c|}
\hline & $\begin{array}{c}\text { burksi } \\
(19 \mathrm{~m}, 19 \mathrm{f})\end{array}$ & $\begin{array}{l}\text { bonitae } \\
(3 \mathrm{~m}, 1 \mathrm{f})\end{array}$ & $\begin{array}{l}\text { dalawangdaliri } \\
\quad(2 \mathrm{~m}, 5 \mathrm{f})\end{array}$ & $\begin{array}{l}\text { ilocandia } \\
\quad(9 \mathrm{f})\end{array}$ & $\begin{array}{l}\text { isangdaliri } \\
\quad(1 \mathrm{f})\end{array}$ & $\begin{array}{c}\text { ligtas } \\
(3 \mathrm{~m}, 2 \mathrm{f})\end{array}$ & $\begin{array}{l}\text { mapalanggaon } \\
\quad(3 \mathrm{~m}, 6 \mathrm{f})\end{array}$ & $\begin{array}{l}\text { tridactylus } \\
(12 \mathrm{~m}, 9 \mathrm{f})\end{array}$ \\
\hline $\begin{array}{l}\text { Number of digits } \\
\text { (fingers/toes) }\end{array}$ & $0 / 0$ & $\begin{array}{l}0 / 0^{\mathrm{a}} \\
2 / 1^{\mathrm{a}}\end{array}$ & $2 / 0-2$ & $0 / 0$ & $1 / 1$ & $2 / 0$ & $0 / 0$ & $3 / 3$ \\
\hline PSV & 51 & 53 & 49 & $50-53$ & 47 & 50 & 51 & 47 \\
\hline MBSR & $21-24$ & $21-24$ & 24,25 & $22-24$ & 22 & 22 & 22,23 & $22-24$ \\
\hline AGSR & $74-85$ & $83-90$ & $80-83$ & $80-82$ & 73 & $74-76$ & $80-84$ & $72-79$ \\
\hline PVSR & $91-102$ & $103-110$ & $97-101$ & $97-100$ & 97 & $91-93$ & 99-102 & $90-98$ \\
\hline SL & 6 & 6 & $\begin{array}{l}6(3) \\
7(4)\end{array}$ & 6 & 6 & 6 & 6 & $\begin{array}{c}6(13) \\
7(8)\end{array}$ \\
\hline IFL & $\begin{array}{l}5(4) \\
6(34)\end{array}$ & 5 & $\begin{array}{l}6(3) \\
7(4)\end{array}$ & $\begin{array}{l}5(3) \\
6(6)\end{array}$ & 6 & 6 & $\begin{array}{l}5(8) \\
6(1)\end{array}$ & $\begin{array}{l}6(13) \\
7(8)\end{array}$ \\
\hline $\mathrm{SC}$ & 5 & 5 & 5 & 5 & 6 & 5 & 5 & $5(21)$ \\
\hline SO & 4 & 4 & 4 & 4 & 4 & 4 & 4 & $4(21)$ \\
\hline Prefrontal contact & Absent & Absent & Absent & $\begin{array}{c}\text { Absent or } \\
\text { Point contact }\end{array}$ & Absent & Absent & Absent & Absent \\
\hline $\begin{array}{l}\text { Frontoparietal } \\
\text { contact }\end{array}$ & Absent & Absent & $\begin{array}{l}\text { Present or } \\
\text { Absent }\end{array}$ & Absent & Absent & Present & $\begin{array}{l}\text { Point contact or } \\
\text { Absent }\end{array}$ & Absent \\
\hline $\begin{array}{l}1^{\text {st }} \text { chin shield pair } \\
\text { contact }\end{array}$ & Absent & Absent & Absent & Absent & Absent & $\begin{array}{l}\text { Present or } \\
\text { Absent }\end{array}$ & Absent & Present or Absent \\
\hline $3^{\text {rd }}$ chin shield pair & Present & Present & Absent & Present & Absent & Present & Present or Absent & Present \\
\hline $\begin{array}{l}\text { Mental } / 1^{\text {st }} I F L \\
\text { fusion }\end{array}$ & Absent & Present & Absent & $\begin{array}{l}\text { Present or } \\
\text { Absent }\end{array}$ & Absent & Absent & Present or Absent & Absent \\
\hline Enlarged nuchals & Present & Present & Present & Present & Present & Present & Present & Present \\
\hline $\begin{array}{l}\text { Longitudinal rows } \\
\text { of dark spots }\end{array}$ & Absent & Absent & Absent & Absent & Absent & Absent & Absent & Absent \\
\hline
\end{tabular}

${ }^{\mathrm{a}}$ Observed for two individuals. 
levels of interpopulation divergences compared with congeners (up to $4.3 \%$ and $5.0 \%$, respectively; Table 2). All monophyletic lineages of the complex recovered in phylogenetic analyses $(B$. bonitae, B. cf. bonitae [Mindoro + Marinduque], B. ilocandia, $B$. isangdaliri, B. ligtas, B. mapalanggaon, and B. tridactylus) are distinguished from each other by levels of genetic divergence greater than or equal to those observed between other species of Philippine skinks (Siler et al. 2011b, 2012a, 2014; Davis et al. 2014).

\section{Morphology}

Multivariate morphological analyses show low levels of variation in mensural characters among the four focal digitless taxa (Fig. 2). The first two PCs account for $59.4 \%$ of the total variance, which loads most heavily on SVL and AGD for PC1 and $\mathrm{HD}$ and HindL for PC2 (Appendix II). With the exception of clear differentiation between $B$. ilocandia and $B$. mapalanggaon along PC2, the remaining four digitless species occupy similar regions in morphospace based on analysis of mensural characters (Fig. 2). Although B. ilocandia and B. cf. bonitae (Mindoro + Marinduque) overlap in morphospace, they display a slight tendency towards taxon-based structure in the data, along PC2 (Fig. 2).

Additionally, when considering the meristic characters, morphological variation confirms the recognition of populations of $B$. cf. bonitae from Mindoro and Marinduque islands as a distinct evolutionary lineage, supporting the results from phylogenetic analyses and examination of genetic divergences (Fig. 1; Table 2). Characters differing between lineages include (1) body size, (2) fore- and (3) hind limb digit states, (4) head scalation and (5) body scale counts, (6) presacral vertebrae number, and (7) coloration/pigmentation patterns, among others (Tables 3, 4; species account below).

\section{Taxonomic conclusions}

Taken together, the results of our phylogenetic analyses (Fig. 1), observed levels of among-lineage sequence divergence (Table 2), allopatric distributions of species (Fig. 1), and a documented suite of diagnostic, morphological character states (Tables 3,4) provide strong support for the lineage on Mindoro and Marinduque islands as a distinct species, for which the name $B$. burksi Taylor 1917 is available.

\section{Taxonomic Account}

\section{Brachymeles burksi Taylor 1917}

(Figs. 3, 4)

Brachymeles bonitae Duméril \& Bibron 1839:777; Brown 1956:5; Brown \&
Rabor 1967:526; Brown \& Alcala 1970:112, 1980:20; Siler \& Brown 2010:1; Siler et al. 2009:449, 2010a:49, 2010b:114, 2011a:53, 2011b:76, 2011c:356, 2011d:300, 2012a:135; Davis et al. 2014:480; Geheber et al. 2016:1; Siler et al. 2016:15.

Brachymeles cf. bonitae Siler et al. 2011a.

Brachymeles burksi Taylor 1917:275; Wagner et al. 2018.

\section{Holotype}

Adult male (CM 1975 [Field No. EHT 700]), collected in Barangay Sumagui (Liddell Plantation), Municipality of Bansud, Oriental Mindoro Province, Mindoro Island, Philippines by E. H. Taylor in 1916; found burrowing under rotting logs and wood.

\section{Referred specimens}

Nineteen adult females (CAS 25712, 25713, 25724, 25782, 25792, 25887, 25889, 25891, 25893-25895, 25899, 25903; CM $65217,65220,65227,65235$; KU 307748, 307749) and eighteen adult males (CAS 62064 [Paratype], 25793, 25880, 25886, 25888, 25896, 25904; CM 1976 [Paratype], 1981 [Paratype], 65203, 65204, 65206, 65225, 65228, 65230; KU 320417, 320418; MCZ 20130 [Paratype]). CAS 25712 was collected along the bank of the Tarogin River, $31 \mathrm{~km}$ southwest of Calapan, Oriental Mindoro Province, Mindoro Island, Philippines $\left(13.1125^{\circ} \mathrm{N}, 121.0853^{\circ} \mathrm{E}\right)$, by A. C. Alcala on 21 April 1963. CAS 25713, 25792, 25887, 25903, and 25904 were collected on the southeast slope of Barawanan Peak, Mt. Halcon, $30 \mathrm{~km}$ southeast of Calapan, Oriental Mindoro Province, Mindoro Island, Philippines $\left(13.1246^{\circ} \mathrm{N}, 121.0448^{\circ}\right.$ E), by A. C. Alcala from 6-13 April 1963. CAS 25724, 25880, 25886, 25888, 25889, 25891, 25893-25896, and 25899 were collected on the southeast slope of Mt. Halcon, $30 \mathrm{~km}$ southwest from Calapan, Tarogin Barrio, Oriental Mindoro Province, Mindoro Island, Philippines $\left(13.1110^{\circ} \mathrm{N}, 121.0820^{\circ} \mathrm{E}\right)$, by A. C. Alcala, C. Batal, R. Empesa, C. Kiskis, S. Magusara, M. Pinero, and A. Trapisado from 30 March-15 April 1963. CAS 25782 was collected in Oriental Mindoro Province, Mindoro Island, Philippines $\left(12.5351^{\circ} \mathrm{N}, 120.5331^{\circ} \mathrm{E}\right.$; data on collectors and date of collection unavailable). CAS 25793 was collected on the southeast slope of Barawanan Peak, Mt. Halcon, Oriental Mindoro Province, Mindoro Island, Philippines $\left(13.1249^{\circ} \mathrm{N}\right.$, $\left.121.0426^{\circ} \mathrm{E}\right)$, by M. Pinero on 8 April 1963. CAS 62064 (Paratype) was collected at Barangay Sumagui, Municipality of Bansud, Oriental Mindoro Province, Mindoro Island, Philippines $\left(12.795317^{\circ} \mathrm{N}, 121.474015^{\circ} \mathrm{E}\right)$, by E. H. Taylor in 1916. CM 1976 (Paratype) was collected in the Municipality of Calapan, Oriental Mindoro Province, Mindoro Island, Philippines by E. H. Taylor in 1916. CM 1981 (Paratype) was collected in the Municipality of Bansud, Oriental Mindoro Province, Mindoro Island, Philippines by E. H. Taylor in 1916. 

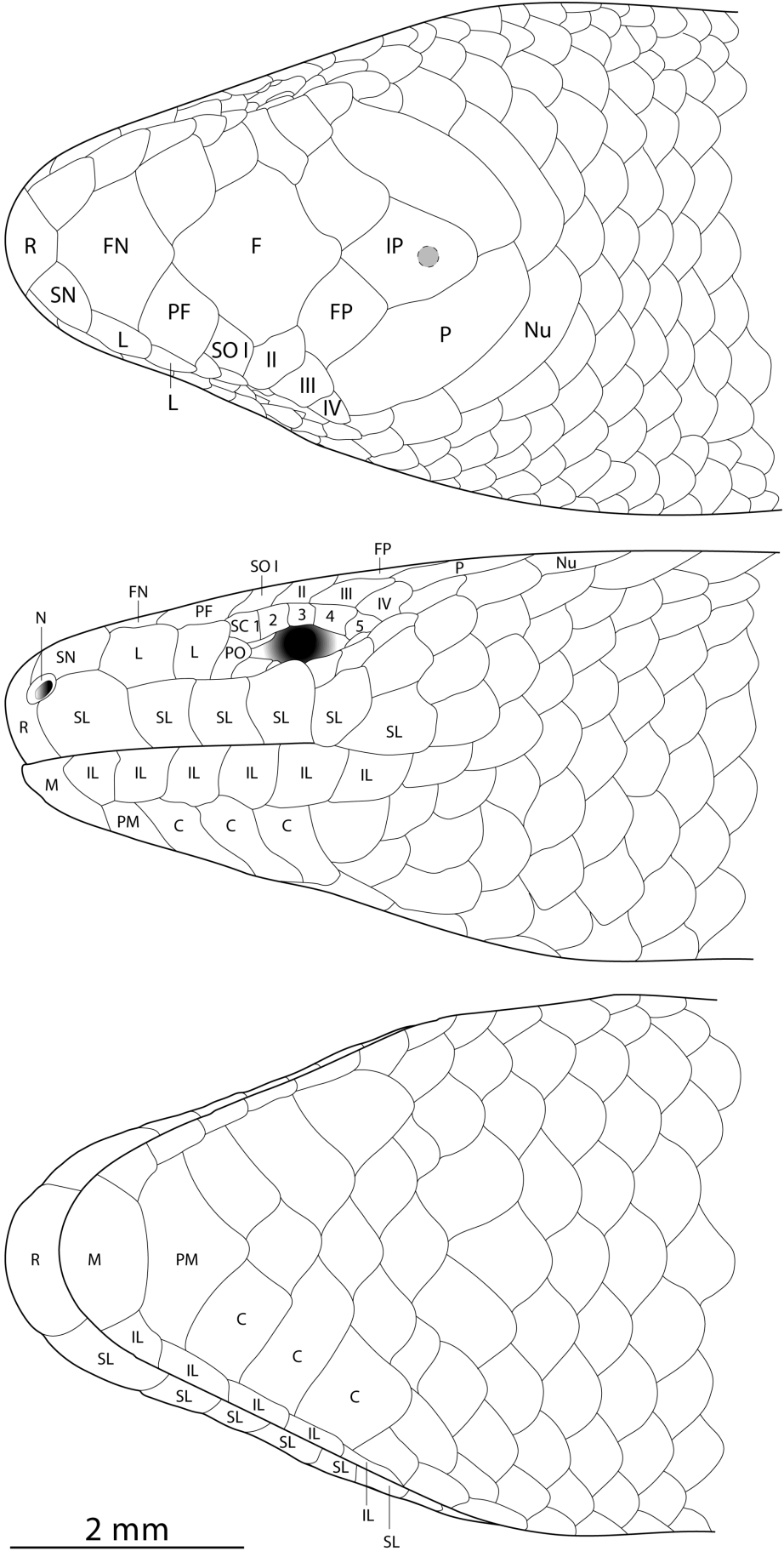

Figure 3. Illustration of the head of Brachymeles burksi (CAS 62064, paratype) from Mindoro Island in dorsal, lateral, and ventral views. Taxonomically diagnostic head scales are labeled as follows: $\mathrm{C}$, chin shield; F, frontal; FN, frontonasal; FP, frontoparietal; IL, infralabial; IP, interparietal; L, loreal; M, mental; N, nasal; Nu, nuchal; P, parietal; $\mathrm{PF}$, prefrontal; PM, postmental; $\mathrm{PO}$, preocular; $\mathrm{R}$, rostral; $\mathrm{SC}$, superciliary; SL, supralabial; SN, supranasal; and SO, supraocular. Roman numerals indicate scales in the supraocular series and Arabic numbers indicating scales in the superciliary series. Illustrations by SNM and ESF.
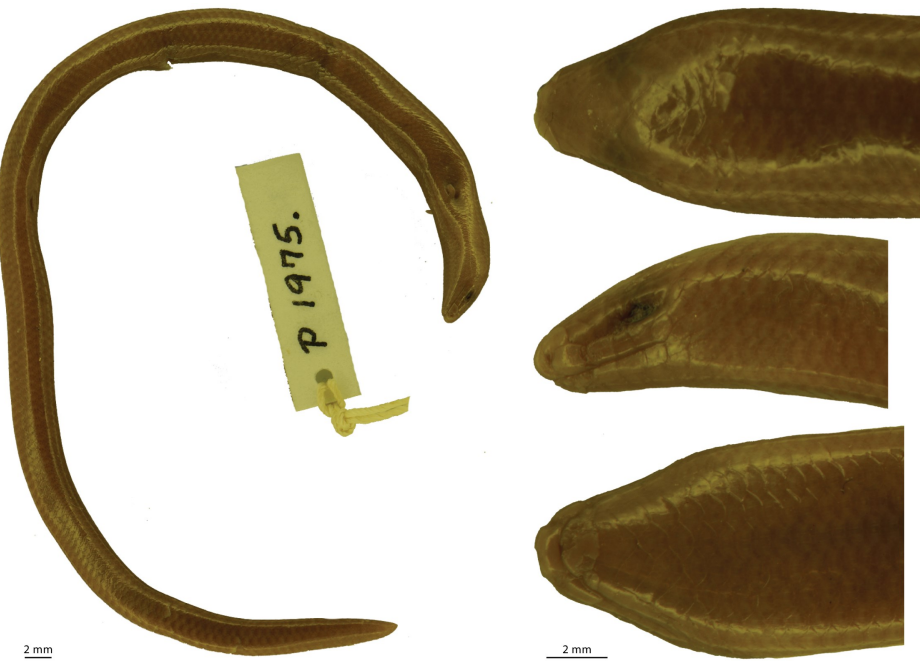

Figure 4. Photographs of the preserved, adult male holotype specimen of Brachymeles burksi (CM 1975 [Field No. EHT 700]) from Mindoro Island showing a lateral view of the whole specimen (left) and closeups of the head in dorsal, lateral, and ventral views (right). Photos by JAS.

CM 65203, 65204, 65206, 65217, 65220, 65225, 65227, 65228, 65230, and 65235 were collected in the Municipality of Boac, Marinduque Province, Marinduque Island, Philippines by R. M. Lumawig from 1971 to 1972 . KU 307748 was collected from Barangay Nicolas, Municipality of Magsaysay, Mindoro Occidental Province, Mindoro Island, Philippines $\left(12.31090^{\circ} \mathrm{N}\right.$, 121.21645 ${ }^{\circ}$ ), by RMB, CDS, and A. C. Diesmos on 10 March 2005. KU 307749 was collected Barangay Malamig, Municipality of Gloria, Mindoro Occidental Province, Mindoro Island, Philippines $\left(12.96505^{\circ} \mathrm{N}, 121.38238^{\circ} \mathrm{E}\right)$, by RMB, CDS, and A. C. Diesmos on 13 March 2005. KU 320417 and 320418 was collected on Mt. Malindig, Municipality of Buenavista, Marinduque Province, Marinduque Island, Philippines $\left(13.24150^{\circ} \mathrm{N}, 122.01360^{\circ} \mathrm{E}\right)$, by $\mathrm{CDS}$ on 21 February 2009. MCZ 20130 (Paratype) was collected in Barangay Sumagui, Municipality of Bansud, Oriental Mindoro Province, Mindoro Island, Philippines $\left(12.795317^{\circ} \mathrm{N}, 121.474015^{\circ} \mathrm{E}\right)$, collected by E. H. Taylor in May 1916.

\section{Diagnosis}

Following recent taxonomic revisions of Brachymeles (Davis et al. 2014, 2016; Geheber et al. 2016; Siler et al. 2016), the new species is assigned to the $B$. bonitae complex based on the following suite of morphological characters: (1) limbs present, (2) non-pentadactyl, (3) paravertebral scale rows $\geq 91$, (4) presacral vertebrae 51, (5) supraoculars four, (6) enlarged, differentiated nuchals present, (7) longitudinal rows of dark spots around the body absent, and (8) auricular opening absent. 
Brachymeles burksi can be distinguished from congeners by the following combination of characters: (1) body size small (SVL 58.4-77.5 mm), (2) fore-limbs digitless, (3) hind limbs digitless, (4) limb length short, (5) supralabials six, (6) infralabials five or six, (7) superciliaries five, (8) supraoculars four, (9) midbody scale rows 21-24, (10) axilla-groin scale rows 74-85, (11) paravertebral scale rows 91-102, (12) prefrontal contact absent, (13) frontoparietal contact absent, (14) enlarged chin shields in three pairs, (15) nuchals enlarged, (16) auricular opening absent, (17) presacral vertebrae 51, and (18) uniform body color (Tables 3,4 ).

\section{Comparisons}

Brachymeles burksi can be distinguished from all limbless species of Brachymeles by having limbs, and from all pentadactyl and reduced-digit species of Brachymeles by having digitless fore- and hind limbs. Among the species in the $B$. bonitae complex, $B$. burksi can be distinguished from $B$. dalawangdaliri, $B$. isangdaliri, B. ligtas, and B. tridactylus by having digitless fore- and hind limbs (versus being unidactyl $[B$. isangdaliri $]$, bidactyl on the fore-limbs $[B$. dalawangdaliri, $B$. ligtas], or tridactyl [B. tridactylus]); from B. bonitae by having fewer presacral vertebrae (51 versus 53), fewer paravertebral scale rows (91-102 versus 103-110), and by the absence (versus presence) of a fused mental with the $1^{\text {st }}$ infralabial scale; from $B$. dalawangdaliri by having more presacral vertebrae (51 versus 49), and by the presence of three paired enlarged chin shields (versus two); from B. ilocandia by tending towards having a smaller body size and shorter limbs based on separation along the axis of PC2 in multivariate analyses (Fig. 2); from $B$. isangdaliri by having more presacral vertebrae ( 51 versus 47 ), more axilla-groin scale rows ( $>74$ versus 73 ), fewer supraciliaries (five versus 6), and by the presence of three paired enlarged chin shields (versus two); from B. ligtas by having more presacral vertebrae (51 versus 50), a smaller relative tail length (61-93\% versus $97-102 \%)$, and by the absence of medial contact between frontoparietals (versus presence); from B. mapalanggaon by tending towards having a larger body size and longer limbs based on separation along the axis of PC2 in multivariate analyses (Fig. 2); and from $B$. tridactylus by having shorter fore-limbs $(0.9-1.5 \mathrm{~mm}$ versus 1.5 $-2.5 \mathrm{~mm}$ ), shorter hind limbs (1.2-1.9 $\mathrm{mm}$ versus $2.6-3.6 \mathrm{~mm})$, and more presacral vertebrae (51 versus 47 ; Tables 3,4 )

\section{Description based on 38 adult specimens}

Details of the head scalation are shown in Figs. 3 and 4; holotype measurements/character states are shown in brackets when available. Body small and slender, SVL $58.4-77.5 \mathrm{~mm}$ $[70.0 \mathrm{~mm}]$; head weakly differentiated from neck, nearly as wide as body, HW $5.3-8.2 \%$ of SVL and $85.3-122.3 \%$ of HL; snout narrow, sharply rounded in dorsal and lateral profile, SNL 46.6-74.3\% of HL; ear completely hidden by scales; eyes small, ED $14.0-22.0 \%$ of $\mathrm{HL}$ and $35.9-54.4 \%$ of END, pupil subcircular; body slightly depressed, nearly uniform in thickness, MBW $83.3-161.0 \%$ of MBH; scales smooth, glossy, imbricate; PVSR 91-102 [98]; AGSR 74-85 [81]; limbs short, diminutive, bluntly rounded, with absent digits on both fore- and hind limb; FLL $1.7-2.4 \%$ of AGD and $1.3-2.1 \%$ of SVL [1.9\%]; HLL 2.4-3.4\% of AGD and 1.6-2.7\% SVL [2.0\%]; tail not as wide as body, TW $74.2-96.2 \%$ of MBW, TL $61.2-93.1 \%$ of SVL [90.7\%].

Rostral projecting onto dorsal snout to level in line with posterior edge of nasal, roughly equal in width and height, in contact with frontonasal; frontonasal wider than long; nostril small, ovoid, in center of single subcircular nasal, longer axis of nostril directed posterodorsally and anteroventrally; supranasals present; postnasals absent; prefrontals not in contact; frontal roughly hexagonal-shaped, its anterior margin in contact with frontonasal, in contact with first two anterior supraoculars, $4.5 \times$ wider than anterior supraocular; supraoculars four; frontoparietals moderate in size, not in contact medially; interparietal moderate in size, its length roughly equal to $1.5 \times$ midline length of frontoparietal, longer than wide, diamondshaped, wider anteriorly, pineal eyespot visible; parietals wider than frontoparietals, in broad contact behind interparietal; enlarged nuchals present; loreals two, anterior loreal longer and slightly higher than posterior loreal; preoculars one or two; presuboculars absent or one; superciliaries five, the anteriormost contacting prefrontal and separating posterior loreal from first supraocular, posteriormost extending to posterior edge of fourth supraocular; subocular scale row single, incomplete, in contact with supralabials; lower eyelid with one row of scales; supralabials six, first twice the width of others, third, fourth and fifth subocular; infralabials five or six (Figs. 3, 4).

Mental wider than long, in contact with first infralabials; postmental single, enlarged, its width equal to, or wider than, width of mental; followed by three pairs of enlarged chin shields, first two pairs moderately separated medially by single scale, third pair broadly separated by three medial scales (Figs. $3,4)$. Scales on limbs smaller than body scales.

\section{Variation}

Differences in scalation patterns were minimal between the holotype (CM 1975) and examined specimens.

\section{Coloration of holotype in life}

Coloration in life was reported by Taylor (1917) as dark brown on dorsal and ventral surfaces, even purplish, with a 
grayish snout. Individual scales were reported as lighter on their edges. Brachymeles specimens do not change color or pattern significantly during preservation (Siler \& Brown 2010; Siler et al. 2011a, 2012a; Davis et al. 2014) and we suspect that preserved and live coloration in $B$. burksi are very similar.

\section{Coloration of specimens in preservative}

The color of dorsal, lateral, and ventral body surfaces and limbs are variably uniform brown, ranging from Burnt Umber (Color 48) in CAS 25886 to Cinnamon-Drab (Color 50) in CAS 62064 (Köhler, 2012). No spotting or striping patterns were observed, nor color differences on the snout, as noted by Taylor (1917) who described the end of the holotype's snout as "grayish."

\section{Etymology}

Taylor named the Mindoro species for his friend and colleague Mr. Clark Burks (Philippine Bureau of Science) who helped with collections in western Mindoro during an ill-fated expedition to Mindoro, which included being caught in a typhoon with depleted food reserves and crew illness and subsequent death due to an outbreak of cholera (Taylor et al. 1975). Fortunately, both Taylor and Burks survived the expedition to Mindoro Island. Suggested common name: Burk's Slender Skink.

\section{Distribution}

Brachymeles burksi is known only from Marinduque and Mindoro islands, Philippines, a distribution that spans two distinct PAICs in the central Philippines: the Mindoro PAIC and the Luzon PAIC (to which Marinduque Island is a member) (Fig. 1). With populations present in two distinct faunal regions, B. burksi possesses an atypical geographic distribution when compared with nearly all other members of the genus, except for B. ilocandia (known from the Babuyan Island Group and the Luzon PAIC; Siler et al. 2016), B. kadwa Siler \& Brown (known from the Babuyan Island Group and the Luzon PAIC; Siler \& Brown 2010), and B. talinis W.C. Brown (known from the Romblon Island Group and the Negros-Panay PAIC; Siler \& Brown 2010).

\section{Natural history}

Although presumed to once predominantly occur in low elevation, primary growth forest, little original habitat remains on Mindoro and Marinduque islands; current populations of $B$. burksi inhabit a matrix of disturbed forest fragments and agricultural areas. The species is secretive and has never been observed in high densities, a pattern consistent with most members of the B. bonitae complex. Brachymeles burksi has been found in sympatry with $B$. mindorensis Brown \& Rabor (Siler \& Brown 2010). Unfortunately, little is known about the ecology and distribution of B. burksi, and comparisons between island populations on Mindoro and Marinduque are warranted. At this time, in evaluating B. burksi against the IUCN criteria for classification, we find that it does not qualify for Critically Endangered, Endangered, Vulnerable, or Near Threatened status, so we consider the lineage Data Deficient pending the collection and assessment of additional information (IUCN 2015) informing on the status of the species' allopatric populations on Mindoro and Marinduque.

\section{Discussion}

With the recognition of $B$. burksi from the islands of Mindoro and Marinduque, 42 species are now recognized in the genus Brachymeles, 40 of which are endemic to the Philippines (Siler et al. 2010, 2016; Davis et al. 2016; Geheber et al. 2016). This island-endemic radiation is a mix of limbless (five species), limbed but non-pentadactyl (19 species), and pentadactyl taxa (18 species). Of the three most species-rich complexes now recognized (B. bonitae, B. gracilis (Fischer), B. samarensis Brown), the $B$. bonitae and $B$. samarensis complexes are composed of non-pentadactyl or limbless species only. Interestingly, the nine recognized members of the B. samarensis complex are distributed across islands of the Mindanao and Luzon PAICs in the east-central and southeastern regions of the country. In contrast, the seven named species of the B. bonitae complex occur on islands in the west-central, central, and northern islands (Siler et al. 2011a, 2016; Davis et al. 2014, 2016; Geheber et al. 2016). Members of both complexes occur on the large, northern island of Luzon; however, the subclades appear to be largely allopatric in their overall distributions on the island, with species of the $B$. samarensis complex being restricted to the Bicol Peninsula and species of the $B$. bonitae complex occurring in south-central, central, and northern Luzon proper. However, recently, a population of B. bonitae was documented for the first time on the Bicol Peninsula of Luzon Island (Municipality of Labo, Camarines Norte Province; Schaper et al. 2018), indicating that there may be greater overlap in the distributions of complex members than currently recognized.

Brachymeles burksi remains one of only two species in the genus native to the island of Mindoro in the central portion of the archipelago-the other species being the pentadactyl $B$. mindorensis. Although we recognize the Marinduque Island population as B. burksi, it is worth noting that its sister relationship with populations on Mindoro Island was unexpected. Studies have shown that parts of northwest Panay 
Island (Buruanga Peninsula), Carabao Island, and the Romblon Island Group were connected to the southwest portion of Mindoro Island as part of the Palawan microcontinental block, which separated from continental Asia roughly 30 Ma (Hall 1996, 1998; Zamoros \& Matsuoka 2004; Yumul et al. 2009a,b; Siler et al. 2012b). However, to our knowledge, Marinduque has never been connected to the Mindoro PAIC, and was, in fact, a land bridge to Luzon during periods of decreased sea level. Given the short branch lengths separating the two sister island populations of B. burksi observed in phylogenetic analyses (Fig. 1), the distribution and close relationship is likely the result of a more recent overseas dispersal event and subsequent colonization of Marinduque Island from Mindoro Island, where we assume B. burski originally evolved in isolation. Despite substantial inter-population genetic divergence (Table 2), we observed broad overlap in standard meristic and mensural characters used for diagnosing lineages within the genus. Therefore, at this time we choose to take a conservative approach in recognizing the two island populations as a single species.

Together with B. ilocandia and B. mapalanggaon, $B$. burksi is the third limbed, but digitless, species in the genus (Davis et al. 2014, 2016; Geheber et al. 2016; Siler et al. 2016). The diversity of body plans within Brachymeles has served as a unique study system for understanding evolutionary transitions in limb and digit morphology in squamate reptiles (Siler \& Brown 2011; Wagner et al. 2018). In fact, B. burksi, as a limbed but completely digitless species, serves as an interesting transitional body state between limbless, snake-like body forms seen in four other members of the genus (B. apus, B. lukbani Siler et al., B. minimus Brown \& Alcala, B. mirimae, and $B$. vermis Taylor) and the diversity of pentadactyl lineages (Wagner et al. 2018).

The species-level diversity within Brachymeles continues to increase as a direct result of three primary factors: (1) continued biodiversity survey efforts at multiple sites throughout the archipelago, (2) collection of high quality, vouchered museum specimens with associated genetic data, and (3) careful examination of historical museum specimens to identify populations with unique suites of diagnostic morphological characters (Siler \& Brown 2010). We expect to eventually see additional species discovered and assigned to the $B$. bonitae complex, including several genetically divergent, isolated populations with unique morphological features already known (Wagner et al. 2018). For example, not only do many small islands within the Luzon and West Visayan PAICs remain poorly surveyed but, also, the intraspecific variation in numbers of digits and presacral vertebrae among populations of $B$. bonitae warrants further attention (Davis et al. 2014). Finally, with the recent discovery of a population of $B$. bonitae in the northern Bicol Peninsula of Luzon Island (Schaper et al. 2018), future survey work should focus on this unique faunal transition zone to better elucidate species distribution patterns and community assembly dynamics.

\section{Author contributions}

CDS conceived the study. CDS, RMB, and ACD conducted fieldwork. CDS and JAS collected morphological data. CDS collected molecular data. ESF analyzed the molecular data. KW analyzed the morphological data. ESF and CDS created final figures. SNM and JAS took specimen photographs. SNM and ESF developed scientific illustrations. SNM initiated writing of early drafts of the manuscript, with final writing efforts by CDS, ESF, DRD, JLW, JAS, KW, and RMB.

\section{Acknowledgements}

We thank the Biodiversity Management Bureau (BMB) of the Philippine Department of Environment and Natural Resources (DENR) for continuing to support and facilitate our biodiversity studies; we are particularly grateful to T. M. Lim, C. Custodio, A. Tagtag, and J. L. De Leon for their logistical support of this research. RMB acknowledges NSF (DEB 0743491 and EF-0334952) for support between 2004 and 2014. Financial support for undergraduate student involvement in this study was provided the University of Oklahoma Undergraduate Research Opportunities Program (UROP) and NSF DEB 0804115 and NSF IOS 1353683 to CDS. For the loans of specimens we thank D. Blackburn, J. Vindum, and A. Leviton (California Academy of Sciences), J. Barnes (Philippine National Museum), J. Ferner (Cincinnati Museum of Natural History), A. Resetar and H. Voris (Field Museum of Natural History), R. Crombie and K. de Queiroz (National Museum of Natural History, Smithsonian Institution), and D. Cannatella and T. LaDuc (Biodiversity Collections, University of Texas at Austin). For access to the Sam Noble Museum Invertebrate Paleontology Stacking Photography Lab we thank S. Westrop and R. Burkhalter.

Finally, we are forever grateful for the career-long support and guidance provided by Dr. Angel Alcala, whose mentorship to $\mathrm{ACD}, \mathrm{RMB}$, and CDS through the years has been beyond impactful.

\section{Literature Cited}

Aurelio, M.A., R.E. Peña \& K.J.L. Taguibao, 2013. Sculpting the Philippine archipelago since the Cretaceous through rifting, oceanic spreading, subduction, obduction, collision and strike-slip faulting: Contribution to IGMA5000. 
Journal of Southeast Asian Earth and Sciences, 72: 102107.

Brown, R.M. \& A.C. Diesmos, 2002. Application of lineagebased species concepts to oceanic island frog populations: the effects of differing taxonomic philosophies on the estimation of Philippine biodiversity. Silliman Journal, 42: 133-162.

Brown, R.M. \& A.C. Diesmos, 2009. Philippines, Biology. In: Gillespie, R. \& D. Clague, (ed.), Encyclopedia of Islands. University of California Press, Berkeley, California, USA. pp. 723- 732 .

Brown, R.M., C.D. Siler, C.H. Oliveros, J.A. Esselstyn, A.C. Diesmos, P.A. Hosner, C.W. Linkem, A.J. Barley, J.R. Oaks, M.B. Sanguila, L.J. Welton, R.G. Moyle, A.T. Peterson \& A.C. Alcala, 2013. Evolutionary processes of diversification in a model island archipelago. Annual Review of Ecology, Evolution, and Systematics, 44: 411435.

Brown, W.C., 1956. A revision of the genus Brachymeles (Scincidae), with descriptions of new species and subspecies. Breviora, 54: 1-19.

Brown, W.C. \& A.C. Alcala, 1970. The zoogeography of the herpetofauna of the Philippine Islands, a fringing archipelago. Proceedings of the California Academy of Sciences, Fourth Series, 18: 105-130.

Brown, W.C. \& A.C. Alcala, 1980. Philippine Lizards of the Family Scincidae. Silliman University Press, Dumaguete City, Philippines. 264 pp.

Brown, W.C. \& D.S. Rabor, 1967. Review of the genus Brachymeles (Scincidae), with descriptions of new species and subspecies. Proceedings of the California Academy of Sciences, Fourth Series, 15: 525-548.

Darriba, D., G.L. Taboada, R. Doallo \& D. Posada, 2012. jModelTest 2: more models, new heuristics and parallel computing. Nature Methods, 9: 772.

Davis, D.R., K.D. Feller, R.M. Brown \& C.D. Siler, 2014. Evaluating the diversity of Philippine slender skinks of the Brachymeles bonitae complex (Reptilia: Squamata: Scincidae): redescription of $B$. tridactylus and descriptions of two new species. Journal of Herpetology, 48: 480-494.

Davis, D.R., A.D. Geheber, J.L. Watters, M.L. Penrod, K.D. Feller, A. Ashford, J. Kouri, D. Nguyen, K. Shauberger, K. Sheatsley, C. Winfrey, R. Wong, M.B. Sanguila, R.M. Brown \& C.D. Siler, 2016. Additions to Philippine slender skinks of the Brachymeles bonitae complex (Reptilia: Squamata: Scincidae) III: a new species from Tablas Island. Zootaxa, 4132: 30-43.

de Queiroz, K., 1998. The general lineage concept of species, species criteria, and the process of speciation: a conceptual unification and terminological recommendations. In: Howard, D.J. \& Berlocher, S.H. (ed.), Endless Forms: Species and Speciation, Oxford University Press, New York. pp. 57-75.

de Queiroz, K., 1999. The general lineage concept of species and the defining properties of the species category. In: Wilson, R.A. (ed.), Species: New Interdisciplinary Essays, Massachusetts Institute of Technology Press, Cambridge, Massachusetts. pp. 49-89.

Diesmos, A.C., J.L. Watters, N.A. Huron, D.R. Davis, A.C. Alcala, R.I. Crombie, L.E. Afuang, G. Gee-Das, R.V. Sison, M.B. Sanguila, M.L. Penrod, M.J. Labonte, C.S. Davey, E.A. Leone, M.L. Diesmos, E.Y. Sy, L.J. Welton, R.M. Brown \& C.D. Siler, 2015. Amphibians of the Philippines, part I: checklist of the species. Proceedings of the California Academy of Sciences, Fourth Series, 62: 457539.

Duméril, A.M.C. \& G. Bibron, 1839. Erpétologie Général ou, Histoire Naturelle Compléte des Reptiles, Tome V. Librairie Encylopédique de Roret, Paris, France, 10: 776778.

Edgar, R.C., 2004. MUSCLE: a multiple sequence alignment method with reduced time and space complexity. $B M C$ Bioinformatics, 5: 1-19.

Geheber, A.D., D.R. Davis, J.L. Watters, M.L. Penrod, K.D. Feller, C.S. Davey, E.D. Ellsworth, R.L. Flanagan, B.D. Heitz, T. Moore, M.D.C. Nguyen, A. Roberts, J. Sutton, M.B. Sanguila, C.W. Linkem, R.M. Brown \& C.D. Siler, 2016. Additions to Philippine slender skinks of the Brachymeles bonitae complex (Reptilia: Squamata: Scincidae) I: a new species from Lubang Island. Zootaxa, 4132: 1-14.

Guidon, S. \& O. Gascuel, 2003. A simple, fast and accurate method to estimate large phylogenies by maximumlikelihood. Systematic Biology, 52: 696-704.

Hall, R., 1996. Reconstructing Cenozoic SE Asia. Tectonic evolution of Southeast Asia (ed. by R. Hall and D. Blundell), pp. 153-184. Geological Society of London Special Publication No. 106, Royal Holloway, University of London, UK.

Hall, R., 1998. The plate tectonics of Cenozoic SE Asia and the distribution of land and sea. Biogeography and geological evolution of SE Asia (ed. by R. Hall and J.D. Holloway), pp. 99-131. Backhuys Publishers, Leiden.

Heyer, W.R., 1972. A new limbless skink (Reptilia: Scincidae) from Thailand with comments on the generic status of the limbless skinks of Southeast Asia. Fieldiana: Zoology, 58: 109-129.

Hikida, T., 1982. A new limbless Brachymeles (Sauria: 
Scincidae) from Mt. Kinabalu, North Borneo. Copeia, 4: 840-844.

International Union for Conservation of Nature (IUCN), 2015. IUCN Red List of Threatened Species. Version 2015.4 Available from: http://www.iucnredlist.org/ (accessed 26 July 2015).

Köhler, G., 2012. Color Catalog for Field Biologists. Herpeton, Offenbach, Germany. 49 pp.

Leachè, A.D. \& T.W. Reeder, 2002. Molecular systematics of the eastern fence lizard (Sceloporus undulatus): a comparison of parsimony, likelihood, and Bayesian approaches. Systematic Biology, 51: 44-68.

Marshall, D.C., 2010. Cryptic failure of partitioned Bayesian phylogenetic analyses: lost in the land of long trees. Systematic Biology, 59: 108-117.

Meneses, C.G., C.D. Siler, J.C.T. Gonzalez, P.L. Wood, Jr. \& R.M. Brown, 2020, Molecular phylogenetic estimates of evolutionary affinities and the first reports of phenotypic variation in two secretive, endemic reptiles from the Romblon Island Group, central Philippines. Philippine Journal of Systematic Biology.

Mittermeier, R.A., N. Myers, P.G. Robles \& C.G. Mittermeier, eds., 1999. Hotspots: Earth's Biologically Richest and Most Endangered Terrestrial Ecosystems. Mexico City: CEMEX.

Myers, N., R.A. Mittermeier, C.G. Mittermeier, G.A.B. da Fonesca \& J. Kent, 2001. Biodiversity hotspots for conservation priorities. Nature, 403: 853-858.

Paradis, E. \& K. Schliep, 2019. ape 5.0: an environment for modern phylogenetics and evolutionary analyses in $\mathrm{R}$. Bioinformatics, 35: 526-528.

R Core Team, 2019. R: A language and environment for statistical computing. $R$ Foundation for Statistical Computing, Vienna, Austria. Available from https://www.R -project.org/.

Rambaut, A., A.J. Drummond, D. Xie, G. Beale \& M.A. Suchard, 2018. Posterior summarization in Bayesian phylogenetics using Tracer 1.7. Systematic Biology, 67: 901 $-904$.

Ronquist F., M. Teslenko, P. van der Mark, D.L. Ayres, A. Darling, S. Höhna, B. Larget, L. Liu, M.A. Suchard \& J.P. Huelsenbeck, 2012. MrBayes 3.2: efficient Bayesian phylogenetic inference and model choice across a large model space. Systematic Biology, 61: 539-542.

Sabaj, M.H., 2019. Standard symbolic codes for institutional resource collections in herpetology and ichthyology: An Online Reference. Version 7.1. American Society of Ichthyologists and Herpetologists, Washington, D.C., USA. Available from: http://www.asih.org/ (accessed 25 March 2019).
Sarewitz, D.R. \& D.E. Karig, 1986. Geologic evolution of Western Mindoro Island and the Mindoro Suture Zone, Philippines. Journal of Southeast Asian Earth and Sciences, 1: 117-141.

Schaper, E.G., P.J. Bergmann, G. Morinaga, J. Fernandez, E.S. Freitas \& C.D. Siler, 2018. Geographic distribution: Philippines, Luzon Island: Camarines Norte Province: Brachymeles bonitae. Herpetological Review, 49: 503.

Schult, V., 2001. Deforestation and Mangyan in Mindoro. Philippine Studies, 49: 151-175.

Siler, C.D., 2010. Squamata, Scincidae, Brachymeles elerae (Taylor, 1917): rediscovery in Old Balbalan, Cordillera Mountain Range, Luzon Island, Philippines, and natural history. Check List, 6: 616-618.

Siler, C.D. \& R.M. Brown, 2010. Phylogeny-based species delimitation in Philippine slender skinks (Reptilia: Squamata: Scincidae: Brachymeles): taxonomic revision of pentadactyl species groups and description of three new species. Herpetological Monographs, 24: 1-54.

Siler, C.D., E.L. Rico, M.R. Duya \& R.M. Brown, 2009. A new limb-reduced, loam-swimming skink (Squamata: Scincidae: Brachymeles) from central Luzon Island, Philippines. Herpetologica, 65: 449-459.

Siler, C.D., A.C. Diesmos \& R.M. Brown, 2010a. A new loamswimming skink, genus Brachymeles (Reptilia: Squamata: Scincidae) from Luzon and Catanduanes Islands, Philippines. Journal of Herpetology, 44: 49-60.

Siler, C.D., D.S. Balete, A.C. Diesmos \& R.M. Brown, 2010 b. A new legless loam-swimming lizard (Reptilia: Squamata: Scincidae: genus Brachymeles) from the Bicol Peninsula, Luzon Island, Philippines. Copeia, 2010: 114-122.

Siler, C.D., A.C. Diesmos, A.C. Alcala \& R.M. Brown, 2011 a. Phylogeny of Philippine slender skinks (Scincidae: Brachymeles) reveals underestimated species diversity, complex biogeographical relationships, and cryptic patterns of lineage diversification. Molecular Phylogenetics and Evolution, 59: 53-65.

Siler, C.D., A.M. Fuiten, R.M. Jones, A.C. Alcala \& R.M. Brown, 2011b. Phylogeny-based species delimitation in Philippine slender skinks (Reptilia: Squamata: Scincidae) II: taxonomic revision of Brachymeles samarensis and description of five new species. Herpetological Monographs, 25: 76-112.

Siler, C.D., R.I. Crombie, A.C. Diesmos \& R.M. Brown, 2011c. Redescriptions of two poorly known slender skinks, Brachymeles bicolor and Brachymeles pathfinderi (Reptila: Squamata: Scincidae), from the Philippines. Journal of Herpetology, 45: 355-369.

Siler, C.D., R.M. Jones, L.J. Welton \& R.M. Brown, 2011d. 
Redescription of tetradactyl Philippine slender skinks (genus Brachymeles). Herpetologica, 67: 300-317.

Siler, C.D., R.M. Jones, A.C. Diesmos, M.L. Diesmos \& R.M. Brown, 2012a. Phylogeny-based species delimitation in Philippine slender skinks (Reptilia: Squamata: Scincidae) III: taxonomic revision of the Brachymeles gracilis complex, with descriptions of three new species. Herpetological Monographs, 26: 135-172.

Siler, C.D., J.R. Oaks, L.J. Welton, C.W. Linkem, J.C. Swab, A.C. Diesmos \& R.M. Brown, 2012b. Did geckos ride the Palawan raft to the Philippines? Journal of Biogeography, 39: 1217-1234.

Siler, C.D., L.J. Welton, A.A. Rock, \& R.M. Brown, 2013. Population genetic structure and revised geographic range for the tridactyl skink (Brachymeles muntingkamay) from Luzon Island, Philippines. Herpetological Review, 44: 3033.

Siler, C.D., C.W. Linkem, K. Cobb, J.L. Watters, S.T. Cummings, A.C. Diesmos \& R.M. Brown, 2014. Taxonomic revision of the semi-aquatic skink Parvoscincus leucospilos (Reptilia: Squamata: Scincidae), with description of three new species. Zootaxa, 3847: 388-412.

Siler, C.D., D.R. Davis, E.S. Freitas, N.A. Huron, A.D. Geheber, J.L. Watters, M.L. Penrod, M. Papes, A. Amrein, A. Anwar, D. Cooper, T. Hein, A. Manning, N. Patel, L. Pinaroc, A.C. Diesmos, M.L. Diesmos, C.H. Oliveros \& R.M. Brown, 2016. Additions to Philippine slender skinks of the Brachymeles bonitae complex (Reptilia: Squamata: Scincidae) II: a new species from the northern Philippines. Zootaxa, 4132: 15-29.

Taylor, E.H., 1917. Brachymeles, a genus of Philippine lizards. Philippine Journal of Science, 12D: 267-279.

Taylor, E.H., A.B. Leonard, H.M. Smith \& G.R. Pisani, 1975. Edward H. Taylor: Recollections of an Herpetologist. The University of Kansas Museum of Natural History, Lawrence, Kansas. 172 pp.

Wagner, G.P., O.W. Griffith, P.J. Bergmann, G.B. BelloHellegouarch, T. Kohlsdorf, A. Bhullar \& C.D. Siler, 2018. Are there general laws for digit evolution in squamates? The loss and re-evolution of digits in a clade of fossorial lizards (Brachymeles, Scincinae). Journal of Morphology, 279: $1-16$.

Welton, L.J., C.D. Siler, A.C. Diesmos \& R.M. Brown, 2009. A new bent-toed gecko (genus Cyrtodactylus) from southern Palawan Island, Philippines and clarification of the taxonomic status of C. annulatus. Herpetologica, 65: 328343.

Welton, L.J., C.D. Siler, A.C. Diesmos \& R.M. Brown, 2010a. Phylogeny-based species delimitation of southern
Philippines bent-toed geckos and a new species of Cyrtodactylus (Squamata; Gekkonidae) from western Mindanao and the Sulu Archipelago. Zootaxa, 2390: 49-68.

Welton, L.J., C.D. Siler, C.W. Linkem, A.C. Diesmos \& R.M. Brown, 2010b. Philippine bent-toed geckos of the Cyrtodactylus agusanensis complex: multilocus phylogeny, morphological diversity, and descriptions of three new species. Herpetological Monographs, 24: 55-85.

Wilcox, T.P., D.J. Zwickl, T.A. Heath \& D.M. Hillis, 2002. Phylogenetic relationships of the dwarf boas and a comparison of Bayesian and bootstrap measures of phylogenetic support. Molecular Phylogenetics and Evolution, 25: 361-371.

Yumul, G.P., C.B. Dimalanta, K.L. Queaño \& E.J. Marquez, 2009a. Philippines, geology. Encyclopedia of islands (ed. by R.G. Gillespie and D.A. Clague), pp. 732-738. University of California Press, Berkeley, CA.

Yumul, G.P., C.B. Dimalanta, E.J. Marquez \& K.L. Queaño, 2009b. Onland signatures of the Palawan microcontinental block and Philippine mobile belt collision and crustal growth process: a review. Journal of Asian Earth Sciences, 34: 610-623.

Zamoros, L.R. \& A. Matsuoka, 2004. Accretion and postaccretion tectonics of the Calamian Islands, North Palawan block, Philippines. Island Arc, 13: 506-519. 
APPENDIX I. Additional specimens examined. Numbers in parentheses indicate the number of specimens examined. Several sample sizes of examined taxa are greater than those observed in Tables 3 and 4, due to the examination of sub-adult specimens which were excluded from morphometric summary statistics and analyses. All species examined are from the Philippines except Brachymeles apus and B. miriamae. Museum abbreviations for specimens examined follow those from Sabaj (2019).

Brachymeles apus (1). BORNEO: Malaysia: Sabah: (SP 06915).

Brachymeles bicolandia (20). LUZON ISLAND: ALBAY Province: Municipality of Malinao: Paratypes (CAS 140065, 152025, 152026); Municipality of Tabaco City: Holotype (PNM 9756), Paratopotypes (KU 324005324011, 324015, 324016, 323087, PNM 9757-9760); Camarines Sur Province: Municipality of Pili: Paratypes (CAS-SU 24173, 24413).

Brachymeles bicolor (24). LUZON ISLAND: AURORA Province: Municipality of Maria Aurora: (KU 323149323152); Cagayan Province: Municipality of Baggao: (CAS 186111, USNM 140847, 498829, 498830, 498833); IsAbela Province: (KU 324097-324099, PNM 5785, 9568 -9577); Kalinga Province: (FMNH 259438).

Brachymeles boholensis (39). BOHOL ISLAND: BOHOL Province: Municipality of Sierra Bullones: Holotype (CAS -SU 24528), Paratypes (CAS-SU 24502-24504, 24518, 24520-24525, 24541, 24543), (CAS-SU 18709, 18717, 24867, 25443, 25444, 25447, KU 323944, 323948, 323949, 323952-323956, 323960, 323962, 323963, 323966, 323970, 323972, 323975, 323976, 323981, 323982, 323990, 324001).

Brachymeles bonitae (7). LUZON ISLAND: LAGUNA Province: Municipality of Los Baños: (MCZ 26585), (CAS 62578); Quezon Province: Municipality of Tayabas: (KU 326089); POLILlO ISLAND: Quezon Province: Municipality of Polillo: (CAS 62278, 62279, 62575, KU 307747).

Brachymeles brevidactylus (3). LUZON ISLAND: SORSOGON Province: Municipality of Irosin: Holotype (PNM 9764), Paratypes (PNM 4856, TNHC 62469).

Brachymeles burksi (38). MARINDUQUE ISLAND: Marinduque Province: Municipality of Boac: (CM 65203, 65204, 65206, 65217, 65220, 65225, 65227, 65228, 65230, 65235); Municipality of Buenavista: (KU 320417, 320418); MINDORO ISLAND: Mindoro ORIENTAL Province: (CAS-SU 25782); Municipality of Baco: (CASSU 25712, 25713, 25724, 25792, 25793, 25880, 25886-
25889, 25891, 25893-25896, 25899, 25903, 25904); Municipality of Bansud: Paratype (CAS 62064), Holotype (CM 1975), Paratypes (CM 1976, 1981), Paratype (MCZ 20130); Municipality of Gloria: (KU 307749); Municipality of Magsaysay: (KU 307748).

Brachymeles cebuensis (8). CEBU ISLAND: CeBu Province: Municipality of Carcar: Holotype (CAS-SU 24400), Paratypes (CAS 102405, CAS-SU 24396, 24397, 24399, 24401, 24403); Municipality of Cebu City: Paratype (CASSU 27537).

Brachymeles cobos (10). CATANDUANES ISLAND: Catanduanes Province: Municipality of Virac: Holotype (PNM 9761), Paratopotypes (KU 306311, 308077, 324019324021, 324025, 324026, PNM 9762, 9763).

Brachymeles dalawangdaliri (7). TABLAS ISLAND: ROMBLON Province: Municipality of San Agustin: Holotype (CAS 137149), Paratypes (CAS 137148, 137150-137154).

Brachymeles elerae (5). LUZON ISLAND: KALINGA PROVINCE: Municipality of Balbalan: (CAS 61499, 61500, PNM 9563, 9564), Paratype (CM 1717).

Brachymeles gracilis (69). MINDANAO ISLAND: DAVAO DEL Sur Province: (FMNH 52642-52644, 52646, 52647, 52662, 52669, 52670); Municipality of Davao City: (CAS 124803, 124804, 139293-139295, 139301-139305); Municipality of Digos City: (CAS 124806-124808, 139296 -139300); Municipality of Kiblawan: (KU 326096, 326098 -326108, 326298, 326299); Municipality of Malalag: (CAS -SU 24158-24165, 24171, CAS 124809-124812, 139306139311); Municipality of Toril: (CMC 12170, 12171); South Cotabato Province: (MCZ 26539, 26541, 26543, 26544, 26546, 26548-26550).

Brachymeles hilong (28). MINDANAO ISLAND: AGUSAN DEL Norte Province: Municipality of Cabadbaran: Holotype (CAS-SU 24407), Paratypes (CAS-SU 102406, 133578, CAS-SU 24411, 133577, 133579, 133581, 133582, 133609, 133612, 133692, 133693, 133703-133706, 133743, 133745 -133747); Agusan del Sur Province: Municipality of San Francisco: (KU 319934-319940); SURIGAO DEL SUR Province: Municipality of Lanuza: Paratype (CAS-SU 24315).

Brachymeles ilocandia (9). CAMIGUIN NORTE ISLAND: Cagayan Province: Municipality of Calayan: Holotype (PNM 9819), Paratopotypes (KU 307967, 308019, 308020, 308027, 308030), Paratype (KU 304567); LUZON ISLAND: Kalinga Province: Paratype (FMNH 259449); LUZON ISLAND: Mountain Province: Paratype (CAS 61377).

Brachymeles isangdaliri (2). LUZON ISLAND: AURORA Province: Municipality of Baler: Holotype (PNM 9791), 
Paratopotype (KU 323085).

Brachymeles kadwa (141). CALAYAN ISLAND: CAGAYAN Province: Municipality of Calayan: Paratypes (KU 304875 , 304897, 304900, 304902, 304903, 304905, 304906, 304915, 304929, 304941, 304908, 304899, 304907, 304909, 304921, 304941); CAMIGUIN NORTE ISLAND: Cagayan Province: Municipality of Calayan: Paratypes (KU 304559, 304575, 304593, 304708, 304754, 307984 , 307996, 307998, 308011，304558，304562$304565, \quad 304569, \quad 304571-304574, \quad 304627-304630$, 304643, 304647, 304696-304699, 304704-304707, 304709 -304712 , 304714, 304753, 304755-59, 307965, 307966, $307985, \quad 307986, \quad 307997, \quad 307999-308003, \quad 308006-$ 308010, 308012-308015, 308017, 308018); LUZON ISLAND: AUrora Province: Municipality of Baler: Holotype (PNM 9721), Paratopotypes (KU 323092, 323094 $-323096,323100,323104,323106,323090,323093$, 323097-323099, 323101-323103， 323105, 323107); Municipality of Casiguran: (KU 323108-48); Municipality of San Luis: (KU 322320).

Brachymeles libayani (45). LAPINIG CHICO ISLAND: BоHOL Province: Municipality of President Carlos P. Garcia: Paratypes (CAS-SU 27556, 28454, 28455); LAPINIG GRANDE ISLAND: Bohol Province: Municipality of President Carlos P. Garcia: Holotype (PNM 9749), Paratopotypes (KU 320428-320430, 320435-320463, 320467, PNM 9750-9755), Paratype (CAS-SU 28453); POLONG DAKO ISLAND: BoHOL Province: Municipality of President Carlos P. Garcia: Paratype (CAS -SU 27554).

Brachymeles ligtas (5). LUBANG ISLAND: Mindoro Occidental Province: Municipality of Lubang: Holotype (PNM 9818), Paratopotypes (KU 320470, 320471, 320473), Paratype (KU 307755).

Brachymeles lukbani (14). LUZON ISLAND: CAMARINES Norte Province: Municipality of Labo: Holotype (PNM 9567), Paratopotypes (PNM 9589-9592, KU 313597313599, 313601, 313603, 313604, 313606, 313608, FMNH 270191).

Brachymeles makusog (17). CATANDUANES ISLAND: Catanduanes Province: Municipality of Gigmoto: Holotype (PNM 9565), Paratopotypes (PNM 9583, 9584, KU 308126, 308128, 308136, 308208); LUZON ISLAND: Camarines Norte Province: Municipality of Labo: Paratypes (KU 313612-313614, 313616, 313617, PNM 9585-9588, FMNH 270200).

Brachymeles mapalanggaon (8). MASBATE ISLAND: Masbate Province: Municipality of Masbate City: Holotype (PNM 9792), Paratopotype (KU 323938);
Municipality of Mobo, Paratypes (CAS 144223, 144236, 144237, 144239, 144270, 144340).

Brachymeles mindorensis (34). MINDORO ISLAND: MINDORO Occidental Province: Municipality of Paluan: (KU $304351-304355, \quad 304412, \quad 304413, \quad 304488, \quad 307739$ 307742, 308404, 308447, 308448, 308534); MINDORO ISLAND: Mindoro Oriental Province: Municipality of Naujan: Holotype (CAS-SU 24487), Paratypes (CAS-SU 24549-24554, 24561, 24562, 24564; 24566, 24568, 24570, 24573, 24574, 24577-24579).

Brachymeles minimus (6). CATANDUANES ISLAND: Catanduanes Province: Municipality of Gigmoto: (KU 308129-308131, 308210-308212).

Brachymeles miriamae (2). THAILAND: NAKHON RATCHASIMA Province: Wang Nam Khieo District: (KU 327692, 327693).

Brachymeles muntingkamay (17). LUZON ISLAND: NUEVA VizCaya Province: Municipality of Quezon: Holotype (PNM 9566), Paratopotypes (PNM 9578-9582, KU 308865, 308866, 308900-308906, 308908, 308953).

Brachymeles orientalis (48). BOHOL ISLAND: BоHOL Province: Municipality of Sierra Bullones: Holotype (CAS -SU 24436), Paratypes (CAS-SU 18702, 24428, 24434, 24437, 24458, 24442, 24446-24451, CAS 102404), (CASSU 25452, 25460); CAMIGUIN SUR ISLAND: CAMIGUIN Province: Municipality of Catarman: (CAS 110976110983); LEYTE ISLAND: LeYTe Province: Municipality of Baybay: (KU 311231-311235, 311241); MINDANAO ISLAND: Agusan del Norte Province: Municipality of Cabadbaran: (CAS-SU 133301, 133616, 133749, 133752, 133754); SAMAR ISLAND: EASTERn SAMAR Province: Municipality of Taft: (KU 305470, 310734-310736, 310739, 310942-310946, 310949, 310951, 310955).

Brachymeles paeforum (13). LEYTE ISLAND: LEYTE Province: Municipality of Burauen: Paratypes (CAS-SU 26110, 26112, 26115, 26120-26123); Municipality of Baybay City: Holotype (PNM 9746), Paratopotypes (KU 311224, 311225, 311224, PNM 9747, 9748).

Brachymeles pathfinderi (40). MINDANAO ISLAND: SARANGani Province: Municipality of Glan: (KU 324057324096).

Brachymeles samad (45). SAMAR ISLAND: EASTERN SAMAR Province: Municipality of Taft: Holotype (PNM 9767), Paratopotypes (KU 310730, 310731, 310820-310827, 310829-310839, 310928-310935, 310937, 310941); LEYTE ISLAND: LeYte Province: Municipality of Baybay City: Paratypes (KU 311216, 311218, 311220, 311221, 311223, PNM 9768-9775).

Brachymeles samarensis (7). SAMAR ISLAND: EASTERN 
Samar Province: Municipality of Taft: (KU 310849310852, 311294-311296).

Brachymeles schadenbergi (34). BASILAN ISLAND: BASILAN Province: Municipality of Maluso: (CAS 60493); MINDANAO ISLAND: Misamis Occidental Province: (CAS-SU 23468, 23469, 23471, 23479-23481, 23484, 23485); Zamboanga del Norte Province: Municipality of Rizal: (CAS-SU 23494-23496); Zambonnga City Province: Municipality of Pasonanca: (KU 314967, 314969, 314970-314978, 314980, 314984, 314985, 314988 -314992, 314994, 314996, 314997).

Brachymeles suluensis (2). BASILAN ISLAND: BASILAN Province: Municipality of Isabela City: (CAS 60365, 60366).

Brachymeles talinis (31). NEGROS ISLAND: NeGRos Oriental Province: Municipality of Valencia: Holotype (CAS-SU 18358), Paratype (CAS-SU 89813), (CAS 133871); Municipality of Dumaguete City: Paratype (CASSU 12225); Municipality of Siaton: (CAS-SU 22311, 22312; 22317, 22323); INAMPULAGAN ISLAND: Guimaras Province: Municipality of Sibunag: (CAS-SU 27972, 27996, 27997); PANAY ISLAND: ANTIQUE Province: Municipality of San Remigio: (KU 306756306760, 306762-306767, 306769, 306770-306776, 306786).

Brachymeles taylori (34). NEGROS ISLAND: Negros Occidental Province: Municipality of Silay City: (KU 324044-324056); Negros Oriental Province: Municipality of Valencia: Holotype (CAS-SU 18615), Paratypes (CAS-SU 18641, 18649, 18656, 18657, 18748), (CAS-SU 21873, 21877, 21880, 21883, 21884, 22355, 22356); CEBU ISLAND: CeBu Province: Municipality of Carcar: (CAS 154671, 154673, 154678-154682, 154686).

Brachymeles tiboliorum (3). MINDANAO ISLAND: SoutH Cotabato Province: Municipality of Tampakan: Holotype (PNM 9777), Paratopotype (PNM 9776); Misamis Oriental Province: Municipality of Tubigan: Paratype (KU 326109).

Brachymeles tridactylus (20). NEGROS ISLAND: NeGRos Occidental Province: Municipality of La Castellana: (CAS-SU 19424, 19426, 19427, 19429, 19452, 19458, 27082, 27083); Negros Oriental Province: Municipality of Manjuyod: Holotype (CAS-SU 18354); PANAY ISLAND: ANTIQUe Province: Municipality of Culasi: (KU 307726-307736).

Brachymeles tungaoi (12). MASBATE ISLAND: MASBATE PRovince: Municipality of Masbate City: Holotype (PNM 9722), Paratopotypes (KU 323934-323936); Municipality of Mobo: Paratypes (CAS 144229, 144230, 144290,
144306, 144307, 144313, 144341, 144342).

Brachymeles vermis (5). JOLO ISLAND: SUlu Province: Municipality of Jolo: Paratype (CAS-SU 62489), (CAS-SU 60720-60722, 60857).

Brachymeles vindumi (4). JOLO ISLAND: Sulu Province: Municipality of Jolo: Holotype (CAS 60724), Paratypes (CAS 60723, 60725, MCZ 26577).

Brachymeles vulcani (20). CAMIGUIN SUR ISLAND: Camiguin Province: Municipality of Mambajao: Holotype (PNM 9766), Paratypes (CAS-SU 26142, 26144-26146, 26165, 26166, 26184, 26185, 26231, 26236, 26294, 26295, CAS 139031); Municipality of Catarman: Paratypes (CASSU 28199, 28314, 28329, 28331, 28358, 28359).

Brachymeles wright (2). LUZON ISLAND: BENGUET Province: Municipality of La Trinidad: Holotype (MCZ 26589), (USNM 140756). 
APPENDIX II. First eight principal components (PC) from multivariate analyses based on 15 mensural characters for the four digitless members of the Brachymeles bonitae complex (B. bonitae, B. cf. bonitae [Mindoro + Marinduque], B. ilocandia, and B. mapalanggaon. See methods for description of abbreviations.

\begin{tabular}{|c|c|c|c|c|c|c|c|c|}
\hline & PC1 & PC2 & PC3 & PC4 & PC5 & PC6 & PC7 & PC8 \\
\hline Standard deviation & 2.52352769 & 1.59469828 & 1.14439282 & 0.96785182 & 0.9028692 & 0.82909094 & 0.69412508 & 0.66359131 \\
\hline Proportion of Variance & 0.42455 & 0.16954 & 0.08731 & 0.06245 & 0.05434 & 0.04583 & 0.03212 & 0.02936 \\
\hline Cumulative Proportion & 0.42455 & 0.59408 & 0.68139 & 0.74384 & 0.79819 & 0.84401 & 0.87613 & 0.90549 \\
\hline Eigenvalues & 6.368192 & 2.54306261 & 1.30963493 & 0.93673715 & 0.81517279 & 0.68739178 & 0.48180962 & 0.44035343 \\
\hline SVL & -0.3386721 & 0.19489663 & -0.2123024 & 0.10307646 & -0.0234346 & 0.10066666 & -0.291687 & 0.00038827 \\
\hline AGD & -0.3164745 & 0.2324021 & -0.1940622 & 0.1069389 & 0.00067148 & 0.12066464 & -0.3994379 & -0.1167223 \\
\hline MBW & -0.196989 & -0.2206333 & -0.3237411 & 0.55721323 & 0.25489288 & 0.14678059 & 0.15099146 & -0.3085881 \\
\hline MBD & -0.2281879 & -0.3220773 & -0.2802745 & -0.0912453 & -0.3897305 & -0.0572256 & -0.2162723 & -0.213891 \\
\hline TW & -0.2707982 & 0.18674557 & -0.2917627 & -0.1990562 & 0.12413598 & 0.29180485 & 0.51213012 & 0.31184219 \\
\hline $\mathrm{TD}$ & -0.2578981 & -0.3190713 & -0.2019494 & -0.1759505 & -0.1923844 & 0.10432981 & 0.35468984 & -0.0801905 \\
\hline $\mathrm{HL}$ & -0.23435557 & -0.0504778 & -0.0093704 & -0.3805996 & 0.70426219 & -0.0357531 & -0.2692715 & -0.0690181 \\
\hline HW & -0.2498266 & -0.3316284 & 0.25169997 & -0.2504207 & 0.1647201 & 0.10186232 & -0.0813516 & 0.25041064 \\
\hline HD & -0.2110625 & -0.4291407 & 0.05904995 & -0.2053621 & -0.2258585 & -0.2386157 & -0.0925172 & 0.06078565 \\
\hline ED & -0.1583542 & -0.0681982 & 0.59186307 & 0.12311455 & -0.1093197 & 0.66161965 & -0.065765 & -0.2129122 \\
\hline END & -0.2830205 & 0.06991522 & 0.34411594 & 0.06323764 & 0.060491 & -0.4577573 & 0.20037087 & -0.3983605 \\
\hline SNL & -0.3091537 & 0.00270122 & 0.22421036 & 0.27007936 & 0.13748073 & -0.2404973 & 0.3357285 & 0.07328403 \\
\hline IND & -0.290567 & 0.01484257 & 0.11405478 & 0.39413741 & -0.1182631 & -0.1659148 & -0.1990992 & 0.65315875 \\
\hline ForeL & -0.2464917 & 0.34832065 & 0.09477226 & -0.2424947 & -0.2929181 & 0.11874325 & 0.1141763 & -0.0101025 \\
\hline HindL & -0.2158803 & 0.43718436 & 0.00952129 & -0.180438 & -0.1474465 & -0.1977663 & -0.0128542 & -0.1856022 \\
\hline
\end{tabular}

